Article

\title{
Religious Education and Sacred Study in the Teachings of Rabbi Yitshak Hutner
}

\author{
Ariel Evan Mayse
}

Department of Religious Studies, Stanford University, Stanford, CA 94305, USA; amayse@stanford.edu

Received: 19 April 2019; Accepted: 9 May 2019; Published: 15 May 2019

\begin{abstract}
Rabbi Yitshak Hutner (1906-1980) was a remarkable scholar, an enigmatic religious intellectual and a charismatic teacher. Drawing upon his public discourses and his written letters, I argue that Hutner's vocabulary-which remained rooted almost entirely in the vocabulary of traditional Talmudism-afforded him a ready garment in which to clothe a syncretic educational theory, which combines Hasidic approaches to spiritual instruction and remakes the traditions of Lithuanian piety and study for his new American audience. The present study interrogates a series of key themes that appear in Hutner's teachings, all of which pertain to issues of pedagogy and the construction of religious education. The essay advances a historical argument by examining the works of an important and influential modern Jewish thinker, but it is also driven by a constructive question: What does Hutner's vision of Jewish religious teaching and learning have to contribute to today's Jewish education, and to the broader world of higher education in North America in particular?
\end{abstract}

Keywords: modern Jewish thought

\section{Introduction}

Rabbi Yitshak Hutner (1906-1980) was many things: a remarkable scholar, an enigmatic religious intellectual, and a charismatic teacher. ${ }^{1}$ Born into Warsaw family with Hasidic roots and deep connections to world of Lithuanian Talmudism, Hutner's religious vision-and his educational philosophy in particular-were shaped by both of these spheres. The young Hutner attended the Slobodka yeshiva and studied under the tutelage of Rabbi Natan Tsevi Finkel (1849-1927), a pietistic Talmud scholar better known as the venerated Alter or "Elder" of Slobodka. ${ }^{2}$ The institution of Slobodka combined rigorous Talmud study with mussar, a certain kind of moralistic introspection developed in the Lithuanian yeshiva world. These intellectual currents, together with the figure of the Alter of Slobodka himself, left their mark on Hutner's religious personality. ${ }^{3}$ Furthermore, in 1925, Hutner left for Palestine, where Rabbi Avraham Yitshak Kook (1865-1935) was an important and controversial cultural and religious force. ${ }^{4}$ It has been convincingly argued that these two charismatic educators-the introspective Talmudic pietist and the extroverted mystic - exerted a formative influence on the young Hutner, whose pedagogy came to embody characteristics of both. ${ }^{5}$ But the peripatetic Hutner returned to Eastern Europe in 1929, sojourned briefly in Berlin where he encountered the likes of Rabbi Joseph B.

1 The scholarly literature on Yitshak Hutner is sparse but insightful. See (Schwarzschild 1985; Goldberg 1987; idem, Goldberg 1989, pp. 63-87; Elman 2017, pp. 303-46; Kaplan 1980; and idem, Kaplan 2010 and Shalev 2013).

2 Other famous graduates of Slobodka included Rabbis Aharon Kotler (1891-1962), Saul Lieberman (1898-1983), and Yehi'el Ya'akov Weinberg (1884-1966), and Harry Austryn Wolfson (1887-1974). See (Goldberg 1989; Tikochinski 2009; Englander 2016).

3 See (Etkes 1993).

4 See (Mirsky 2014).

5 See (Goldberg 1987, p. 23). 
Soloveitchik (1903-1993) before returning to Warsaw. In the mid-1930s, Hutner moved to the United States and, although he moved to Israel before his death, he spent most of his remaining years on American soil.

It was in the United States that Hutner came to inhabit his own creative and pedagogical voice. Hutner did maintain enduring, if complicated, relationships with many of the other Ultra-Orthodox Jewish leaders that had emigrated from Europe, from transplanted Lithuanian elites like Rabbi Aharon Kotler (1891-1962) to Hasidic tsaddikim like Rabbi Yoel Teitelbaum of Satmar (1887-1979) and Rabbi Menachem Mendel Schneerson of Chabad-Lubavitch (1902-1994). ${ }^{6}$ But to a large degree, Hutner struck out on his own. Starting in 1936, he sat at the helm of Yeshiva Chaim Berlin in Brooklyn, and over the course of many decades he developed a curious hybrid theology and pedagogy all of his own. Above all else, Hutner came to embody the role of a teacher and religious educator; much of his creative effort was spent in passing on his thought and theology to his students through public addresses and personal correspondence. ${ }^{7}$

Themes orbiting the importance of religious education and its nature dominate the monthly homilies or discourses delivered at Hutner's yeshiva across some four decades. These addresses, given in Yiddish with a particular cadence and with much excitement and emotion, were later reconstructed, translated into Hebrew and written down. Eventually they were published in a series called Pahad Yitshak, at first anonymously and then under Hutner's own name. ${ }^{8}$ Hutner's discourses follow the holiday cycle, thus grounding his theology and educational philosophy in the phenomena of lived practice rather than abstract categories. ${ }^{9}$ They introduced Hasidic thought, Kabbalistic ideas, and philosophical notions to his students without doing so overtly; with few exceptions he cloaked such reflections within the normative discourse of Lithuanian Talmudism. ${ }^{10}$ Though very much an Ultra-Orthodox thinker, with a complicated relationship to the secular and an increasingly anti-Zionist stance, he was open to-and to a certain extent excited by-aspects of Western knowledge. ${ }^{11}$ Hutner's eclectic and synthetic approach, one in which innovation is hidden within the mantle of tradition, comes across in the discourses that serve as the primary data for this study.

Hutner's discourses are one of the textual cornerstones of scholarship addressing his life and thought. But they are not the only data resources available to scholars. Though he rarely gave public addresses beyond the walls of his own yeshiva, Hutner was a prolific writer and an avid correspondent. My analysis of his teachings on education will; therefore, make use of a volume of several hundred letters and other assorted writings. This volume, posthumously published in 1981, includes the written account of a few public lectures and open letters. But most of the collected epistles were addressed to individual students rather than the entire community of disciples. The private letters evince a tenor and vision that differs from the public addresses and; thus, offer a window into a different part of Hutner's religious personality and his understanding of the Jewish education. ${ }^{12}$

The present study interrogates a series of key themes that appear in Hutner's teachings, all of which pertain to issues of pedagogy and the construction of religious education. The first of these is Hutner's emphasis on the paramount importance of discipleship. The relationship between the student and the master, at once distant and intimate, was central to his educational project. Hutner understood the enigmatic, allusive power of charismatic leadership. Honor due to teachers, as we

6 See (Goldberg 1989, pp. 77-80; Dalfin 2019).

7 Among Hutner's many disciples were Rabbi Ahron Soloveitchik (1917-2001) and Rabbi Aharon Lichtenstein (1933-2015), and his daughter Bruria David (née Hutner, b. 1938), who became a noted educator in Israel.

8 Hutner's teachings were published anonymously before 1964.

9 See (Goldberg 1987, p. 38).

10 See (Elman 2015; Halivni 1996, p. 148).

11 It should be noted that Hutner's daughter earned a doctorate from Columbia, where she worked with Salo Baron and wrote her dissertation on Rabbi Zvi Hirsch Chajes, a nineteenth-century European Talmudist whose own life and intellectual world spanned modern and traditional realms.

12 See (Bashevkin 2016), online, accessed 24 March 2019. 
shall see, was also an important theme in his teachings; his students' recollections make clear that in his own life Hutner very much stood on ceremony. Hutner's descriptions portray the ideal teacher is a soulful educator, a fusion of the Lithuanian rosh yeshiva and the Hasidic rebbe. ${ }^{13}$ Offering far more than religious instruction or conveying ideas, ${ }^{14}$ Hutner argued that students should be fundamentally transformed by their encounter with the educator's religious personality and the essence of his being.

The master-disciple bond is the core of his educational enterprise, but it is a relationship that does not exist in isolation. The community of students, claims Hutner, also forms a critical element of religious education. He argues that spiritual growth requires a community of seekers and fellow students who, for at least a time, create an environment saturated with devotional intensity and intellectual creativity. Hutner's approach reflects the educational ideal of the Lithuanian yeshiva, fused with Hasidic notions of the mystical fellowship, and models spiritual friendship. ${ }^{15}$ To better understand this aspect of the sacred community, I believe that putting Hutner's teachings into dialogue with contemporary notions of the community of practice and theories of situated learning will yield particular insight. ${ }^{16}$

The third theme that characterizes Hutner's vision is his description of religious education as a project of self-formation rooted in the praxis of sacred study. The study of Torah-and of Talmud in particular-is itself a mode of devotion and of communion with the Divine. This may seem unsurprising for a traditional Jewish thinker, but we shall see that, despite his allegiance to Lithuanian patterns of learning, Hutner also departs from Talmudic exclusivity and from intellectual totalism. He paints an emotive vision of study and education as cultivating and fostering one's creative potential, emphasizing connection to tradition through innovation reinterpretation, and constant renewal. ${ }^{17}$ For this reason, claims Hutner, education is best undertaken in one's youth, a time of physical change and intellectual foment that mirrors the ever-shifting nature of the cosmos.

This accent upon inner creativity reflects the fact that Hutner saw education as something far more dynamic than "banking" information in the student. ${ }^{18}$ The disciple's encounter with the teacher and with the community is meant to spark inspiration beyond simple content transfer, producing new textual interpretations and a concomitant process of self-recreation. Hutner's emphasis on the autonomy of the disciple contrasts, often paradoxically, with his demands for honor and reverence-bordering on submission - to the teacher. This dynamic, tension-laden, and paradoxical as it may be, was illustrated in his own life. Hutner neither emulated nor copied his teachers, and none of Hutner's students duplicated his own intellectual peregrinations. His yeshiva was an insular community, but many of his students went on to university in some form. The quest for self-formation through encountering the text yielded different results for different students, and rather than bemoan their eventual departure from the yeshiva, Hutner encouraged his students to go out into the world and leave their mark upon it.

The fourth and final element of his thought that concerns me here is Hutner's understanding of education and study as forces and processes that are partial or incomplete unless they transform all aspects of one's life. The life of the commandments, the world of religious praxis, must be enriched and transformed through the project of education. Study and religious knowledge should give additional intellectual texture to the life of devotion, grafting ideas to the rhythms and rituals ordained by Jewish law. But, argues Hutner, one's intellectual education must extend beyond the classical commandments and/or simply-construed "religious" practices. All of one's deeds and moments, the full totality of one's life in the world, must be infused with learning and with the fruits of religious education.

\footnotetext{
13 See (Schachter-Shalomi 1991; Feldman 1996; Magid 2012; Ferziger 2013).

4 See (Wringe 2009); and, more broadly (Epstein 1981; Guenther 1992).

5 See (Stampfer 2012; Fine 2013, pp. 61-75); and (Green and Mayse 2016), online, accessed 24 March 2019

See, in particular, (Brown et al. 1989; Anderson et al. 1996; Mezirow 1996).

(Elman 2014).

8 (Freire 2011, pp. 117-27); and, more broadly, idem, (Freire 2018).
} 
Examining Hutner's teachings on education will require us to hold together many conceptual worlds, since his multi-layered and marbled theology draws upon a wide range of influences. Citations from classical Jewish sources-Hebrew Bible, Talmud and rabbinic literature, and medieval authorities (especially Maimonides and MaHaRaL) —are the stock-in-trade of his books, as they were for the great Lithuanian Talmudists of previous generations. But Hutner has garbed critical inflections of mussar, Hasidism, and twentieth-century philosophy in this mantle of Talmudism, producing an old-new theology for his American yeshiva students. ${ }^{19}$

I would argue that this linguistic phenomenon was part and parcel of his educational project. Hutner's Hebrew—and his Yiddish—is filled with the unmistakable markers of the learned rabbinic idiom. In this he has much in common with Joseph B. Soloveitchik, another scion of Lithuanian Talmudism who traveled through Western Europe and staked his educational claim on American shores. Soloveitchik's journeys are embodied in his distinctively pluralistic language that blends together echoes of Hasidism, German philosophy, modern romanticism, Talmudic dialectics, and medieval Jewish thought. Soloveitchik's languages were, in a sense, de-territorialized by his erudition and his intellectual migrations. Not so for Hutner, whose vocabulary-which remained rooted almost entirely in the vocabulary of traditional Talmudism-provides a ready garment for a syncretic educational theory, which combines Hasidic approaches to spiritual instruction and remakes the traditions of Lithuanian piety and study for his new American audience. ${ }^{20}$

My present goal is to interrogate the complexities of Hutner's writings on religious education, diving into the textual and conceptual mélange that they represent. Getting at these issues will require us to dovetail analysis of his theological and personal writings with modern educational theory, examining possible points of connection as well as tension. I then aim to explore what the writings of this religious intellectual have to offer twenty-first century educators. My essay advances a historical argument in examining the works of an important and influential modern Jewish thinker, but it is also driven by a constructive agenda: What does Hutner's vision of Jewish religious teaching and learning have to contribute to today's Jewish education, the goals of which are often quite diverse and diffuse? ${ }^{21}$ Moreover, what does Hutner have to say to spiritual education in the post-modern age, to education in our broader culture of North America, and to the world of higher education in particular? ${ }^{22}$

\section{Master and Disciple}

The relationship between teachers and students has been a core theme in Jewish sources, stretching back to the Hebrew Bible and forward to modern Jewish philosophy. ${ }^{23}$ The master-disciple model might rightly be described as the heart of rabbinic Judaism, but it took on particular importance in the literatures and social formations of Jewish mysticism. The figure of Rabbi Shimon bar Yohai stood as the axis mundi of a circle of disciples (called the hevraya) in the thirteenth-century Zohar. ${ }^{24}$ Rabbi Yitshak Luria (1534-1572), the charismatic leader at the heart of the Safed mystical renaissance, patterned his own community of students upon the imagined hevraya of the Zohar. ${ }^{25}$ The socio-religious movement

19 See also (Abrahamov 2000; Herskowitz and Shalev 2018; Schwarzschild 1985, pp. 235-77). To my knowledge Hutner was not personally acquainted with Rabbi Kalonymous Kalman Shapira (1889-1943), another creative rabbinic leader and thinker from Warsaw. There are important echoes of Shapira's educational philosophy expressed entirely in Hutner's discourses, where such pedagogical insights are expressed in the language and vocabulary of Lithuanian Talmudism. On Shapira's educational vision, see, most recently (Leshem 2018).

20 See (Stampfer 2012; Lamm 1989; Silverstein 2010; Hartstein 1947; Turner 2000).

21 (Fox et al. 2003); and, for an important attempt to derive educational theory from the broader philosophical writings of Jewish thinkers, see (Cohen and Holzer 2008-2009).

22 See also (Fowler 1996); idem, (Fowler 2001; Wexler 2014).

23 See, for example, (Bialik and Ravnitzky 1992, pp. 414-19, 427-29; Rubenstein 1999, pp. 34-63, 64-104; Handelman 2012; Jaffe 1997; Ben-Menahem 2008, pp. 288-305; Aberbach 1967, pp. 1-24; Blidstein 1975). See also Maimonides, Mishneh Torah, hakdamah; ibid., hilkhot talmud torah, chap. 5-6; ibid., Perush ha-Mishnah on m. Avot 1:6; Num. 19; Num. 20:22-29; Num. 27:12-22; Josh. 1:1-9; I Kings 19:16-21; II Kings 2; and II Kings 5:20-27; and (Assis 2004, pp. 25-42).

24 See (Liebes 1982, pp. 1-84).

25 See (Fine 2003, pp. 1-18, 78-123). See also (Scholem 1997, pp. 251-73; Fishbane 2012). 
of renewal called Hasidism, which grew out of the teachings and vision of Rabbi Israel ben Eliezer of Mezhbizh (c. 1700-1760), was driven by charismatic leaders and spiritual educators together with their groups of disciples. ${ }^{26}$

Hutner likely absorbed something of the emphasis on master and disciple from these earlier literatures. But the power of charismatic education was one that he had seen embodied in the living example of the Alter of Slobodka and Avraham Yitshak Kook, as well as the twentieth-century Lithuanian scholars ${ }^{27}$ and the Hasidic sages of Warsaw and Brooklyn. ${ }^{28} \mathrm{He}$ argued that the role of a religious educator must carry with it a very different set of responsibilities than those born by a teacher of math or history. Hutner argued that the distinction between these two kinds of education must be clear to the teacher, but also to the students themselves. In a 1962 address to the Yeshiva of Eastern Parkway, which opened as a branch of Yeshiva Chaim Berlin in 1946, Hutner recalls asking a young student to compare his connection to a teacher of Torah with that to an instructor of secular subjects:

"You have a rabbi, with whom you study Talmud, and-distinguishing the sacred from the profane-you have a teacher (moreh) with whom you study secular subjects. ${ }^{29}$ Is your relationship with both of them equal? Or do you feel a difference in your relationship with them?" ...

He thought for a few moments, then gave voice to this radiant explanation: "My relationship to the teacher of secular subjects is like that of an individual who receives food from the hand of one who cooked the food. By contrast, my relationship to the rabbi is like one who receives food from a nursing woman (meineket). ${ }^{\prime 30}$ The nursing woman sustains the one who sucks with the essence of her life, whereas the cook gives something that comes entirely from the outside. ${ }^{31}$

This moving portrait of religious education as breast-feeding is built upon the rabbinic association of students as a teacher's children, a comparison that is oft-cited in post-Talmudic literature and which appears frequently in Hutner's own homilies. ${ }^{32}$ The striking image of the spiritual master as a nursing mother has a rich history in Jewish sources, ${ }^{33}$ many of which draw together the opaque biblical description of Moses as a "nurse" or "nursing-father" (omen) and the well-known Talmudic adage: "more than the calf wants to suck, the cow wants to suckle." ${ }^{34}$ Such sources imply that the

26 See (Sharot 1980; Green, forthcoming; Idel 2012, pp. 79-106; Garb 2011, pp. 113-14, 144, and 214 n. 104-6). There is a wealth of material from Hasidic literature on the art of spiritual education; see (Mayse, forthcoming a; Leader 2019, pp. 177-202; Friedman 2003, pp. 112-36; Jacobs 2005, esp. pp. 90-99 and 100-20; Solomon 2000).

27 It is worth recalling the following remarks by Joseph B. Soloveitchik in a Yiddish homily from the 1950s: "The teacher must give his deepest, hidden, and intimate truth to the disciple, inviting him-just, as it were, as the Master of the World did with all creation - to take part in his own existence. The student and teacher are poured into one another through an act of compassion. Just as God is revealed to humanity through nature, and the apocalyptic revelation of shekhineh comes via prophecy, so too is the teacher revealed to the student. He entrusts him with his intimate, quiet ' $\mathrm{I}$ ', and through this trust they are united with one another. Two souls poured into a single mystical personality." See (Soloveitchik 2009, p. 223). Translated in (Mayse 2019a), online, accessed 24 March 2019.

28 With characteristic insight, (Goldberg 1987, p. 22) notes: “If the Elder addressed the whole person, restricting the flow of knowledge in accord with the powers of receptivity of the addressee. Rabbi Kuk addressed the heart and the mind, unleashing torrents of discourse woven from the entire range of Jewish thought: law, lore, philosophy, poetry, mysticism, pietism, homiletics, exegesis. The Elder was a pedagogue; Rabbi Kuk, an intellectual. Isaac Hutner sought to combine the two, to become the two."

29 The italicized words appear in English (with Latin letters) in the original Hebrew.

30 In Talmudic literature, this term can refer to a nursing mother or a wet-nurse. See b. Yevamot 36b; b. Ketubbot 65b; and b. Niddah $7 \mathrm{a}$ and $9 \mathrm{a}$.

31 Yitshak Hutner, Pahad Yitshak-Iggerot u-Mikhtavim (Brooklyn: Gur Aryeh, 2016), no. 74, p. 134.

32 See b. Sanhedrin 99b: "Reish Lakish said: 'One who teaches Torah to the child of another, the verse considers him as though he formed him, as it says, "and the souls they formed in Haran" (Gen. 12:5)'."

33 See Num. 11:12; and, more broadly, (Benjamin 2018, pp. 65-73, 98-110). See also (Walfish 2017, pp. 307-25; Haskell 2012).

34 b. Pesahim 112a. See also Bereshit Rabbah 30:8; and (Handelman 1992). It is worth noting that Targum Yerushalmi renders the word meniktah ("nurse") in Gen. 24:59 as padgevatah, which may be translated as "guardian," "nurse," or "teacher." This calls to mind the formulation in Gal. 3:24: "Therefore the law was our disciplinarian (paidagogos) until Christ came, 
teacher sustains his students with Torah and religious instruction, just as a mother nourishes and enlivens her child with milk.

Hutner's particular use of this image highlights the intensity of the bond between master and disciple, emphasizing that the teacher shares something essential with his students. Just as milk is produced by the mother's body, religious instruction is generated by the teacher's mind and heart. Once imbibed, this vital force fuels the student's spiritual metabolism and stimulates religious growth. ${ }^{35}$ This is evidently true only for the teacher of Torah, since Hutner claims that one who teaches "secular subjects" is doing no more than passing along external forms of information. The result is a repercussive and transformative moment for the student and the teacher-the nursing mother-alike. ${ }^{36}$

The image of education as breast-feeding also makes clear that the encounter between the teacher and the student is personal and intimate. The nurturing link between them is deeply and inherently private and not meant for the public. The master, like a nursing woman, can ideally sustain only one child at a time. This point is drawn out more clearly in the continuation of the address: "Surely you know that it is possible to cook for a community at once, but it is impossible to suckle a community at the same time. Nursing (hanakah)—this is a matter of private encounter (yehidut). ${ }^{37}$ Chefs may cook up a large batch of food and produce a comestible that sustains the entire community; each person receives whatever he or she needs from the same dish. Proper spiritual education, claims Hutner, requires particular attention to the needs of the individual, because the message is not universally applicable. ${ }^{38}$ The power of such thoughtful instruction, best had in oral communication, leads to a personal connection between the master and disciple that enables above and beyond any transfer of knowledge.

It is no surprise that Hutner's lecture, addressed to the entire student body, begins with a caveat: speaking to many people at once-whether verbally or in writings-is a compromise. "My true desire," claimed Hutner, "to speak with each and every one of you alone." ${ }^{39}$ The lack of flexibility in group communication is felt most acutely in writing; Hutner notes elsewhere that "it is utterly impossible to submerge the tip of the quill into the depths of the heart." ${ }^{40}$ The ideal of intimate spoken words may not always be realized, but it remains the central paradigm and both sides must keep it in mind when the master addresses the group.

The preference for orality has been a key part of Jewish discourse on education from rabbinic times. ${ }^{41}$ It is certainly true for Hasidism, where the immediacy of lived encounter and spoken words are the fundaments of religious education. ${ }^{42}$ But remarks on orality and education are also present in the writings of the philosopher Moses Mendelssohn (1729-1786), who decried the loss of a sense of vital engagement with other human beings that resulted from the turn toward printed books as the arbiters of knowledge and culture. Rather than communion between two living souls, he describes the focal point of Berlin intellectual society as trained to the written word. Painting this transition in such dire terms served Mendelssohn's own philosophical goal of defending the validity of the Oral Law,

so that we might be justified by faith." See (Lull 1986); and, on the Greek and Roman background of the pedagogue as a slave, tutor, or teacher charged with caring for the child's wellbeing, see (Young 1987; Yannicopoulos 1985; Bonner 1977, pp. 34-47; Corrington 1989).

35 On Torah as compared to milk, see Shir ha-Shirim Rabbah 4:2, commenting on Song. 4:11.

36 See (Demetrakopoulos 1982; Gandolfo 2013); and, more broadly, (Shulman 1986).

37 Pahad Yitshak-Iggerot u-Mikhtavim, no. 74, p. 134. On the personal encounter, see (Etkes 2005, pp. 31-47, 94-95); and Schachter-Shalomi, Spiritual Intimacy.

38 Here we should note the Mahayana Buddhist concept of upāya or upāyakauśalya, often translated as "skillful means" and referring to a kind of pedagogy through specifically-tailored means of education. See (Harrison 2003).

39 Pahad Yitshak-Iggerot u-Mikhtavim), no. 74, p. 134.

40 Yitshak Hutner, Pahad Yitshak-Hanukkah (Brooklyn: Gur Aryeh, 1989), no. 11, p. 100.

41 See (Elman and Gershoni 2000; Abrams 1996; Fishbane 2009, esp. pp. 53-60, 84-99, 114, 122).

42 Tradition recalls an early Hasidic sage making the following claim: "With you people (i.e., the opponents of Hasidism), the Hasidim are one thing, and the teacher and the teachings are another. That is why you need written texts. We, our teacher, and the teachings were all truly one. We had no need for written texts." As translated in (Green 2013a, vol. 1, p. vii). See also (Mayse and Reiser 2018), and the relevant literature cited therein. 
but his mournful complaint reveals an important aspect of the cultural reformations in early modern Western Europe. ${ }^{43}$

Despite his protestations regarding the priority of oral instruction, Hutner did take to the written word to maintain his correspondence with students. ${ }^{44}$ Laudatory reflections on writing, such as the following, are particularly common in these letters:

The spoken word said through the lips dissipates like froth above the water. While a word etched in lead will stand permanently for safekeeping. So too, there are emotions which dissipate quickly, while other feelings remain permanently through time. It is easy to understand that for an emotion that will easily dissipate it is fine to express through the spoken word-which too will fly away like a bird. But an emotion which is created permanently in the heart must be protected on paper. ${ }^{45}$

One would do well, it seems, to given verbal expression to fleeting experiences or feelings. Such sentiments, like the spoken word, soon take wing and depart from the vista of one's consciousness. But other ideas, defined by their gravitas and steadfast nature, require the permanency and stability of written language. Furthermore, as Hutner argues in another letter, a religious idea set into writing has the additional virtue, because people are far more likely to pay it mind and treat it with the respect it requires. ${ }^{46}$

Rather than an emphasis on pure orality, Hutner's thinking reveals an interesting tension in regard to the written and spoken mediums of religious education. Both modes of communication have their place in the attempt to convey information and meaning from master to disciple. Personal-oral-instruction provides immediacy and personal engagement. It cuts against the institutionalization of religious education, a phenomenon to which Hutner was staunchly opposed, although he begrudgingly accepts its existence. Oral instruction, he felt, returned the student-and the teacher-to the original site and modality of revelation at Sinai:

Teachers today must be prepared to leap over the lost links; it is the vocation of us all today to extract what is noble from what is worthless. Our distinction vis-à-vis all previous generations of teachers it that our mouths must become like the mouth of the Holy One. We must effect the Giving of the Torah to the souls. ${ }^{47}$

The power of oral instruction derives from revelation, ${ }^{48}$ reflecting the great and ever-unfolding discourse of Oral Torah. ${ }^{49}$ This body of knowledge was never really transcribed or codified, says Hutner, but it was written down in an elliptical form. One must have a teacher in order to find one's way, and, in guiding the student, the teacher himself becomes like God. We should remember that the Jewish God is often described as a teacher, an image captured succinctly in the rabbinic blessing recited before study: "Blessed are You ... Who teaches Torah to His people Israel." 50 In the Talmudic imagination, God's teachings are, of course, Scripture and the ever-expanding discourse stemming from it, and the modern-day teacher embodies this entire dynamic.

This theory of education hinges upon personal relationship, and upon the in-person encounter in particular. ${ }^{51}$ "One who merits to recognize true sages of Israel (gedolei yisra'el amiti'im)," writes Hutner, "sees this (i.e., spiritual richness of the inner world) with his very eyes, in a tangible way." 52

\footnotetext{
(Mendelssohn 1986, p. 103).

See also (Mayse, forthcoming b; Mayse and Reiser 2018, pp. 127-60).

See Pahad Yitshak-Iggerot u-Mikhtavim, no. 183, p. 273, translated with marvelous felicity in (Bashevkin 2016), online.

Pahad Yitshak-Iggerot u-Mikhtavim, no. 267, p. 337.

As translated in (Carmy 1981, p. 224).

See (Green 2013b, pp. 237-65; Polen 2010, pp. 123-53); and idem, (Polen 2015, pp. 55-70); and (Mayse, forthcoming a).

Pahad Yitshak-Iggerot u-Mikhtavim, no. 32, pp. 53-55.

b. Berakhot $11 \mathrm{~b}$.

Leader, “Leadership as Individual Relationships," pp. 177-202.

Pahad Yitshak-Iggerot u-Mikhtavim, no. 74, p. 136. See Maimonides' summary of the laws in Mishneh Torah, hilkhot talmud torah 6:1-14; and see also m. Avot 4:12, and the comments of Rabbi Yonah Gerondi ad loc.
} 
This encounter inspires love in the student's heart and reveals new possibilities. It also produces awe or fear, necessary counterbalances to the love that also defines the disciple's relationship with the teacher. Hutner claims that although honor (kavod) is due unto all religious educators and learned sages, before one's own teacher the disciple must be stricken with awe and fear. ${ }^{53}$

Showing deference to a sage is linked to their status as venerated and hoary elders of the community. The honor that a disciple must show to his personal teacher; however, has a very different root. Rather than abstract reverence for wisdom or age, this awe-struck fear and reverence reflect the fact that instruction from master to disciple is a kind of revelation. More precisely, the engagement of living teacher and student is a reawakening and recreation of the theophany at Sinai. ${ }^{54}$

By cultivating this tempering force, says Hutner, the student mirrors the awe-inspiring theophany at Sinai and is granted access to the ideational and educational riches of that revelation. Hutner argued that this sort of honor was sorely missing from the educational structures of twentieth-century America, often underscoring the special imperative for such honor in the present day. ${ }^{55}$ Students have forgotten that passion and fiery devotion shape the experience of study, he argued, emotions that turn ordinary Talmudic scholarship into divine relation. Reverence for the teacher and reverence for the ever-unfolding divine word; thus, go hand in hand.

Circling back to the beginning of the discourse, Hutner cites the rabbinic sages who note that one verse demands "unto Him you shall cleave" (Deut. 13:5), but cites the impossibility of such unmediated encounter. Is God not described as a "consuming fire" (Deut. 4:24)? Can one cleave to such a God? No, the Sages admit, but one may fulfill the injunction through cleaving to the sages and their disciples. ${ }^{56}$ Hutner then adds a new dimension to the discussion:

Fulfilling the commandment of cleaving to shekhinah splits into two [different] paths-[becoming attached through the] sages and the students .... The obligation of cleaving to shekhinah is not fulfilled through cleaving to a sage's student because of the student's own personhood. But cleaving to the sage's disciple fulfills [the command] of cleaving to shekhinah through the connection of the student to the sage, his teacher. ${ }^{57}$

This point about the transparent nature of a student's connection to his master is most remarkable. In cleaving to the student, one becomes attached to the teacher, whose imprint rests upon the disciple that has become a mirror, speculum, or perhaps a conduit for his master's words. ${ }^{58}$ This connection to chain of spiritual lineage leads one all the way back to the Source. Hutner then continues:

The commandment of teaching Torah (harbatsat torah) is expressed in the language of "and you shall teach them to your children" (Deut. 6:7) ... The act of teaching Torah is like a single two-sided coin, since teaching Torah to disciples—who are called children-is a matter without end (ein sof). Rather the upshot of teaching Torah is creating children through the power of Torah study. That is, it is possible for a person to receive every kind of property, all sorts of belongings of the things of the world, from someone else. But it is impossible for one to receive the essence of the existence of life ('etsem metsiyut ha-hayyim) from any source other than the father.

Fatherhood is the only existence that allows one to bestow life-existence upon another. Accordingly, we say disciples are only called "children" once the Torah passed on to them is

\footnotetext{
53 See Yitshak Hutner, Pahad Yitshak-Shavu'ot (Brooklyn: Gur Aryeh, 2018), ma'amar 8:27, p. 80.

54 See (Mayse 2019b).

55 Pahad Yitshak-Shavu'ot, ma'amar 8:30, pp. 81-82; Pahad Yitshak-Iggerot u-Mikhtavim, no. 132, pp. 222-24.

56 See Sifrei on Deuteronomy 11:22, quoted in RaSHI ad loc. Mishneh Torah, hilkhot de' ot 6:2. Cf. b. Sotah 14a, for the injunction of cleaving to God through works of love and kindness toward others; and (Rapoport-Albert 1979; Green 1977).

57 Pahad Yitshak-Shavu'ot, ma'amar 18:7, p. 132.

58 See also Rabbi Nahman of Bratslav's comments in Likkutei Moharan I:140.
} 
considered not an external worldly possession, but a value that is identified with the body of life itself .... .

This is teaching Torah, when considered to us as a coin with two sides: passing on the Torah on one side, and creating children on the other. They are not [separate] two things that just happen to be brought together in a single inn. ${ }^{59}$

Previously we found Hutner describing the act of religious education as nursing. But here the metaphor has been flipped, presented in the masculine language and invoking the imagery of fatherhood. ${ }^{60}$ The teacher gives life to the students, just as a father gives life to the children he sires. This gift of this animating life-force only becomes fully realized; however, when the disciples allow the vital Torah to seep into the marrow of their soul.

The transmission of content and the transformation of the disciple must not, Hutner argues, be misunderstood as divisible or even complementary processes. The ideal educational form is one in which the teacher's words arrest the student and become part of his or her fundament. This is precisely why one can connect to a master through cleaving to his disciples. The radiant disciple reflects - or better, embodies-the spiritual riches of his master, becoming a radiant translator of his teacher's wisdom that will ultimately lead others back to the source. In concluding, Hutner spins things further by asking why the rabbinic exegesis explains that one may cleave to "sages and their disciples." Rather than two separate options-cleaving to a master, or, if that proves impossible, connecting to his disciples-Hutner reads it is a single compound imperative: the most powerful expression of Torah appears when the master and his disciples are together: "Only when the sage and the disciples are found together, only in a such a place does the power of generativity hidden in the Torah rule." ${ }^{11}$

Thus Hutner draws a line of educational and theological importance through his entire discourse. How does one cleave to God? Through becoming connected to Torah, a religious discourse embodied in the sages. One cleaves to the students, and through them, reaches to the teacher and then into the infinite and ever-unfolding pool of divine wisdom to which they have achieved access. The impassioned connection of the students and the teacher means that the master too has greater access to divine wisdom, becoming attached to shekhinah and infusing the entire community with new wisdom and illumination.

Of course, this paradigmatic bond cannot necessarily be achieved with all of one's disciples. He is careful to emphasize those students that have fully imbibed the master's lessons, metabolizing the ideas such that they become a part of the body and soul, rather than extrinsic information or concepts layered upon the body like a scholastic exoskeleton. How does this come to be? Through an intimate connection between the master and disciple. The students become children, as it were, because they are created by the parent-the life-force of the master gives them vital animating force. These modalities-teaching Torah, and creating children —are not two distinct stages, but rather two different angles on the very same process of religious education.

Neither can all disciples become as one's children. Such privilege is reserved for what the Talmud describes as talmidim muvhakim, students with whom a master has deep and ongoing relationships founded in a shared intellectual experience. "Raising up a single primary disciple (talmid muvhak) takes precedent over raising up many students who are not thus." ${ }^{\prime 2}$ This intense bond is held up as the ideal, and Hutner even suggests teaching everyone is an ancillary obligation branching forth from the primary obligation of establishing the deep connection. All student-teacher relationships are echoes, as it were, of that ideal form that the master-disciple may become.

59 Pahad Yitshak-Shavu'ot, ma'amar 18:7, p. 133.

60 See also the passage translated in (Carmy 1981, p. 224).

61 Pahad Yitshak-Shavu'ot, ma'amar 18:12, p. 135.

62 Pahad Yitshak-Shavu'ot, ma'amar 29, p. 186. Rabbinic literature also presents a notion of the rav muvhak, a primary teacher to whom one's honor is due. See b. Bava Metsia 33a; Mishneh Torah, hilkhot talmud torah 5:9; Shulhan 'Arukh, yoreh de'ah 242:30; and (Cooper 2010). 
A master-disciple relationship of this rung and caliber is surely not the work of a moment. While it is true that in some cases one does not need to meet a charismatic teacher more than once to have his mind awakened and his life transformed, in most cases it takes a very long time. In a letter to a student, Hutner explores two seemingly distinct rabbinic teachings. The first dictum is that one is obligated to visit his master (le-kabbel penei rabbo), literally to "receive his face," of their master on a holiday. ${ }^{63}$ The other is the Talmudic truism a student cannot fathom his teacher's mind ('omed 'al sof $d a^{\prime} a t$ rabo) before forty years. ${ }^{64}$ Weaving these traditions together, Hutner describes a series of rungs in a student-teacher relationship. The first stage is receiving his words on the intellectual plane, perhaps understanding them and even reinterpreting. The student has not yet fathomed their inner depths. To achieve this stage, far beyond simple comprehension, the student must come to see the inherent, fundamental connection between the master's religious personality and his spiritual instruction. ${ }^{65}$

Whether or not the disciple has achieved this level of apprehension, claims Hutner, is readily discernable. If a student cannot bear to hear the same teaching more than once, for example, this reveals a deficit in his grasp of his teacher's words. The same is true if the disciple is annoyed when he or she cannot immediately understand the master's teachings. A student must pay rapt attention to the teacher's lesson even when hearing it delivered for the hundredth time, remembering that he will find new depth and meaning in his master's words either then or in the future.

This is why it may-or better, must—-take "forty years" for a student to fathom the mind of his teacher. This interval gestures toward a period of extended time of unpacking and reinterpreting, in which the disciple becomes alert to the ongoing echoes encoded or hidden within the master's teaching. A student who wrongly assumes that all meaning or content should be immediately comprehensible is in fact denying the essential dynamism of religious education. Unlike the animal that remains the same from the day it was born, human beings are defined by innate capacity for change and transformation. ${ }^{66}$ A disciple evolves and matures over the course of the decades, and only then will he come to see the power of his teacher's remarks. "Receiving the face of the master on the holiday," says Hutner, means that one grasps not only external words but "the connection between the master's essence and the words of his Torah. ${ }^{\prime \prime 7}$ Education rests upon developing one's sensitivity to the inward quality of a master's words. ${ }^{68}$

There is an unmistakable autobiographical layer to Hutner's ruminations and reflections on the master-disciple relationship. The image of a disciple spending decades absorbing the lessons absorbed in his youth seems to reflect Hutner's early experiences with Alter of Slobodka and Avraham Yitshak Kook, charismatic figures whose words unfolded across the years as Hutner grew into them and changed himself. Furthermoe, the ideals of the master-disciple were clearly something Hutner sought to embody in his own career as an educator. Hutner lamented the fact that religious education had become institutionalized and professionalized, thus becoming sterilized and largely denatured. ${ }^{69}$ He developed sustained relationships with his many disciples, connections that were at once intimate and somehow enduringly distant.

63 b. Sukkah 27b; b. Rosh Hashanah 16b. In a work that may well have been known to Hutner, the nineteenth-century Hasidic sage Tsevi Elimelekh Shapira offered the following reflections on why a student is obligated to visit his master on the holiday in his Benei Yissakhar (Benei Berak: 2015) hakdamah: "When holy times come, supernal sanctity flows forth from the source of holiness to all. Yet the student cannot be compared to the master (whose ability to receive is much greater). Nonetheless, when the student enters the presence of the master, they become as one. Each one faces the other, the giver and the receiver, with intimacy and trust. They become as one flesh, and it is like lighting a flame of our candle from another."

64 See b. 'Avodah Zarah 5b, and RaSHI's comments to Deuteronomy 29:6.

65 Pahad Yitshak-Iggerot u-Mikhtavim, no. 12, p. 20.

66 See Bava Kamma 65a.

67 Pahad Yitshak-Iggerot u-Mikhtavim, no. 12, p. 21.

68 Though he does not make it explicit, Hutner seems to be playing with the similarity of "face" (panim) and "innerness" (penimiyyut) - hence, one must seek to pierce the inner quality of his master's words over the period of forty years, and during the in-person encounters in particular.

69 See (Carmy 1981, p. 218). 
Hutner's students frequently noted that he was zealous in ensuring that his students were serious about issues of honor and ceremony, taking umbrage if they forgot to address him with proper respect or if they turned their back after a conversation. ${ }^{70}$ Indeed, in one of his letters Hutner underscores the pedagogical importance of remoteness, both physical and psychological. This is because excessive familiarity prevents the disciple from paying attention to the master. ${ }^{71}$ Hutner sought to foster a sense of healthy independence among his disciples. This sense of proper distance came together; however, with deep intellectual and emotional engagement in their religious development. ${ }^{72}$ Such affection is clearly visible in his letters, but it comes through—if more obliquely—-through the way that Hutner's discourses recast his inner world in the language of Lithuanian Talmudic scholarship, sharing his personal theology with his students through a commitment to education founded in love.

\section{The Community}

The master-disciple relationship, the nucleus of Hutner's educational vision, neither emerges nor functions within a vacuum. He understood that the religious journey is, for the most part, a quest that must be undertaken in a communal setting. Hutner argues that this ongoing interaction between student and teacher must—at least for a time-be embedded within a broader educational framework. Although being part of a community may obscure the individual's deficiencies, which may not be revealed until he leaves, Hutner often stresses that communal experience builds upon and amplifies the strengths of each individual student. ${ }^{73}$ Generating a kind of centrifugal educational force, the intense inner life of each individual—and his relationship to the spiritual master—radiates outward and infuses the communal practices of prayer, study, and so forth, with additional meaning and intensity.

Jewish literatures across the centuries have offered many different models of educational frameworks, spiritual communities and mystical fraternities. ${ }^{74}$ Many of these were known to Hutner. But he saw the institution of the yeshiva as the educational community most effective at incubating true spiritual growth. ${ }^{75}$ As Hutner had seen with the Alter in Slobodka, a yeshiva may become a hotbed of spiritual creativity, an educational environment with unique strengths when it comes to producing students of intellectual and emotive strength. Additionally, thought Hutner, the yeshiva was a model that could not only be transplanted to the American context, but could flourish there in unique ways.

Paralleling his command that religious teachers embrace their unique task, Hutner exhorts his students to see their role in yeshiva as different than students applying themselves to other forms of knowledge and education. In the 1962 address to the students of the Yeshiva of Eastern Parkway, recalled in brief above, Hutner notes: "Surely you know about Rabbi Hayyim of Volozhin. When he established the yeshiva in Volozhin, he entered a change of terminology in regard to the life of the yeshiva. He distanced the phrase "students of the yeshiva" (talmidei ha-yeshiva) and in its place employed "children of the yeshiva" (benei ha-yehivah)."76 Hutner's intellectual tradition goes back, to some degree, to the Volozhin yeshiva and its approach to the study of Torah and to education. ${ }^{77}$ Here he deploys that claim to lineage to illustrate that the pupils of a yeshiva are not merely "students" but "children" or, better, "sons of the yeshiva."78 This lexical shift, based on the Talmudic tradition of

\footnotetext{
See the reflections from one of Hutner's students in (Goldberg 1987, p. 31).

Pahad Yitshak-Iggerot u-Mikhtavim, no. 155, pp. 244-45.

Pahad Yitshak-Iggerot u-Mikhtavim, no. 135, pp. 225-26; ibid., no. 107, pp. 196-97; and ibid., no. 100, p. 190.

See his reflections in Pahad Yitshak-Iggerot u-Mikhtavim, no. 64, p. 119.

See (Green and Mayse 2016; Weiss 1997, pp. 155-69).

See (Stampfer 2012; and idem, Stampfer 1996; Cooper 2018).

Pahad Yitshak-Iggerot u-Mikhtavim, no. 74, p. 134

In addition to the sources noted above, see (Etkes 2007, pp. 39-52; Helmreich 1982; Schacter 1990; Magid 2000).

(Heilman 1992, p. 227): "A ben (son of the) yeshiva was a person who had gone through the Lithuanian-style nonhasidic yeshiva system and who, because he had assimilated its values and worldview, continued throughout his life to draw his Jewish identity from that experience... He was someone steeped in Jewish tradition and the details of Jewish law. He was not simply governing his behavior according to the norms of the street-even if that street was a Jewishly observant one. He was part of a rabbinic elite."
} 
students as children, reflects Hutner's interpretation of how the Lithuanian tradition transformed the ideal of a yeshiva into a famille spirituelle for intense inner work.

Reminding students that they are beloved children rather than students bespeaks several educational goals. It stretches a familial fabric around the students, creating a sense of intimate devotional community among the boys and young men in his institutional. Spiritual fraternity changes the way that they see their own job while in yeshiva, and how they relate to one another within the heightened spiritual confraternity that circulates around the sacred text. But creating this interpersonal bond also reminds the students that they must not approach the curriculum as an external body of wisdom to be accumulated in the mind. Sacred texts, claims Hutner, must be seen as internal to the self, as a life-giving discourse akin to mother's milk. Finally, the designation of students as children shapes how they view the master and disciple relationship at the core of the community.

Leaders who attempted to founding a strong yeshiva culture have, at times, done so in order to create an educational environment that is fully insulated from outside influences. ${ }^{79}$ That was certainly part of the picture for Hutner, but he affords a much more positive and less entrenched vision of the yeshiva. Cutting against the usual refrain of "the decline of the generations" (hitkatnut or yeridat ha-dorot),${ }^{80}$ Hutner notes that there are greater virtues of being in yeshiva in his generation than at any time before. ${ }^{81}$ He offers a riddle to explain his point: Normally one who does not eat "royal dainties" (ma'adanei ha-melekh) will not expire from hunger, since he will simply turn to a lesser grade of foodstuff to satisfy his needs. Yet a Jewish child cannot truly live without the delights of Torah; they are a delicious comestible, as it were, but they are one that student can neither replace nor live without. ${ }^{82}$ There are dire consequences for turning away from study, from the "royal dainties" of Torah-expiration from spiritual hunger. Invoking the biblical warning of "take heed to yourselves, lest your heart be deceived, and you turn aside, and serve other gods, and worship them" (Deut. 11:16), ${ }^{83}$ Hutner quotes a well-known principle in physics:

The soul of a person abhors a vacuum. ${ }^{84}$ If one does not fill the space with Torah, the vacuum will be filled up with all sorts of mundane things. This opens the door to idolatry. This is what is said in the verse from the Shema: If one turns away from Torah, the door remains open for other gods. This is the true for every individual, in all times. ${ }^{85}$

Hutner's internalized re-reading of "nature abhors a vacuum" (horror vacui) ${ }^{86}$ calls to mind teachings from the Ba'al Shem Tov on this same verse, which underscore that turning the mind away from God is the gateway to all sin and idolatry. ${ }^{87}$ He notes that although the principle may not be scientifically true, it is still useful grist for the exegetical mill and he applies the postulate to the inner life of the individual. The yeshiva is necessary for religious education, says Hutner, because it is an environment that fosters such focus and contemplative attunement that there is no room for a vacuum:

The Pentateuch speaks of two kinds of structures: the Tabernacle was built, and the ark was built. The Tabernacle is built when everything outside of it was in the best of order, but one

\footnotetext{
79 See the 1919 appeal to found a new Hasidic academy in inter-bellum Warsaw translated in (Biale et al. 2018, p. 602): "We need to open the gate to a house for the multitudes, a yeshivah, which will be a fortress; a fortress for the Torah, a guard tower for worship and a fire wall for religion and faith. And whoever seeks life-shall flee into this place and live."

80 See (Kellner 1996; Jacobs 1996, pp. 200-13).

81 Pahad Yitshak-Iggerot u-Mikhtavim, no. 75, p. 137.

82 See also the well-known parable of the fishes who refuse to flee to dry-land in order to escape the fisherman, attributed to Rabbi 'Akiva in b. Berakhot $60 \mathrm{~b}$.

83 See RaSHI's comments on this verse.

84 The italicized words appear in English.

85 Pahad Yitshak-Iggerot u-Mikhtavim, no. 75, p. 138

86 (Efros 1916).

87 See Degel Mahaneh Efrayim (Jerusalem: 2011), kedoshim, pp. 388-89; and the BeSHT's oft-cited exegesis of Psalm 32:2. See also (Heschel 1976, p. 43).
} 
needed a special place for holiness; therefore, building a tabernacle. But the ark is built when a flood is destroying everything and everyone.

In most generations, the yeshiva was a tabernacle. Jewish life outside the tabernacle was in order, and the yeshiva was a special place upon which the name of God is called.

In our generation; however, the yeshiva is an ark. Outside of this ark there is a deluge of heresy and ignorance that floods over and silences everything and everyone, without exception. ${ }^{88}$

Twentieth-century Jewish literature, from before the Holocaust as well as after it, describe the modern yeshiva as a "fortress" or a bastion of Orthodoxy, an institution meant to staunch the tides of educational or religious reform and secularism. But the yeshiva, says Hutner, must be more than a structure into which to retreat from the floodwaters of heresy and secularism. The real point of the instruction is the sacred activity and spiritual creativity that happens within.

The yeshiva, like the biblical ark, has firm and impermeable walls. These boundaries deliver the occupants from the turbulent waves that crash over exterior. In this sense it is insular and inward looking. But the yeshiva is also a kind of Tabernacle or Temple, a dwelling place for the Divine amongst the community of devoted seekers. ${ }^{89}$ Having been set aside and designated a sacred space for inner work, the yeshiva is transformed into an educational structure in which the sacred community may come into its own.

We might expect Hutner to demand that his students remain in such a place throughout their life. But he writes that the point of religious education in this kind of community is to effect a lingering inner transformation, a series of awakenings that endure well after the student leaves the educational environment of the yeshiva. In fact, suggests Hutner, the enduring dimension is a sine qua non of religious education and the best measure of such education's success. In a personal letter, he offers the following parable to a student:

When water is placed in vessels that are set upon the fire, it is impossible to know how much water is in the vessels while they continue to stand upon the fire. The boiling heat of the fire causes the water to send up bubbles, which reach the very lip of the vessel. Only after it has been removed from the flame, [after] the heat has stopped working upon it, does it become possible to determine which vessel is filled with water, and which are only half, a third, or a quarter full.

This applies equally to those who leave the yeshiva. When a person remains inside the walls of the yeshiva, he is upon the fire. The boiling inner voices of Torah and awe are working upon his soul. Even if there is much emptiness, the boiling prevents it from being visible at that time. The little material in his soul fills the entire space. But after he is taken off the fire and leaves the yeshiva, the burning stops and it is possible to truly know the measure of spiritual content found in the heart of this child of the yeshiva.

In this, I express my hope that the rest of your future life does not extinguish the coal from whose fire you have drawn warmth. ${ }^{90}$

The yeshiva is a veritable pressure-cooker of devotional energy. This intense educational framework allows for inner work, philosophical inquiry, Talmudic learning, and spiritual development. It is not; however, the ultimate goal that all students remain in this place forever. In fact, the power of religious education is; thus, revealed retroactively: Does the fire of worship continue with autonomous devotional passion once the student has gone out into the world?

88 Pahad Yitshak-Iggerot u-Mikhtavim, no. 75, p. 138.

89 See Ex. 25:8, and, more broadly, (Margolin 2005).

90 Pahad Yitshak-Iggerot $u$-Mikhtavim, no. 97, p. 187. 
Leaving yeshiva after many years of study tests the degree to which the lessons have really percolated in the disciple. For many, including most of Hutner's students, going out in the world is the telos and a necessary stage of religious growth. He supported this in full, chastening disciples who saw the choice to leave yeshiva as duplicitous. To one such student, he writes:

The general impression that one receives from your words is the simplistic assumption by you that a secular career is a double life. ${ }^{91}$ It is superfluous to tell you that I would never agree, in any way, to [the notion of] a double life. Indeed, one who rents a room in a house to live in it as a resident, and rents another room in the hotel to dwell in it as a guest, surely he has a double life. But someone who rents a dwelling of two rooms has a broad life not [a] double life. ${ }^{92}$

Among the primary goals of religious education is becoming attuned to how to construct a "broad" or unified life of integrity. Time in yeshiva allows one to see that the goals of a spiritual life do not contradict involvement in the broader world. Rather than duplicity or hypocrisy, a life lived in consonance with one's spiritual goals is one of expansiveness and breadth.

My dear beloved, heaven forfend that you see yourself as a duplicitous liar, living a double life. [The Talmud says:] if an individual extends the "one" [of "Hear, O Israel, Y-H-V-H is our God, Y-H-V-H is one"] (Deut. 6:4), his days and years are extended. ${ }^{93}$ Your entire life must be of the quality of "extending the one" - one, and not double. I will be greatly pained on your account, my beloved, if this point is hidden from your eyes.

Many points that are spread out, one beneath the other, surely reflect some multiplicity. But if these same points are arranged around the perimeter of a single point at the center, they become a single circle. This, my beloved, is your obligation in this world: to stand at the center of your life of oneness. Then you have no cause to fear at all for multiplicity. Each new point that you acquire for yourself will only expand the circle, but the unity will not depart from its place. ${ }^{94}$

This paradigm means that all the various movements of one's life and career, far beyond the confines of the yeshiva of one's youth, may be drawn together like points along the perimeter of a circle. ${ }^{95}$ It requires courage, of course, and demands ongoing effort. But one can incorporate most phenomena of existence into one's religious life, because the educational power of the yeshiva has given a framework, a hierarchy of values—or circle—of values in which the quest for God lies at the very center. This confidence also generates a certain kind of religious activism, a capacity to effect positive change in the broader world:

The state of holiness in our days requires that people who take pride in the glory of holiness must act upon the mundane (hol), like a foot that leaves a footprint upon the sand (hol). The footsteps of the Messiah are, above all, the footprint of holiness upon the mundane. ${ }^{96}$

[The word] hol has two meanings-[physical] sand, and mundane (hullin). Just as the physical heel acts upon sand below it, so does the heel of holiness act upon mundane things that are below it. In our generation, it is impossible for us not to have some action of bringing close the ordinary things that surround us...

91 The italicized words appear in English

92 Pahad Yitshak-Iggerot u-Mikhtavim, no. 94, p. 184.

3 b. Berakhot 13b.

94 Pahad Yitshak-Iggerot u-Mikhtavim, no. 94, p. 185.

95 See b. Ta'anit 31a: "In the future the blessed Holy One will arrange a circle of the righteous, and He will sit among them in the Garden of Eden. Each and every one will point with his finger, as it says: 'And it shall be said on that day: "Behold, this is our God, for whom we waited, that He might save us. This is the Y-H-V-H; for whom we waited. We will be glad and rejoice in His salvation" (Isa. 25:9)'." This text was much beloved and commented upon in Hasidic works.

96 Emphasis in the original. 
My beloved, I would be delighted to hear that at least one Israelite soul was brought near to the heavenly Father by you. ${ }^{97}$

Holiness in the present generation cannot be static or insular, argues Hutner, and it must tread upon and influence the world. Unlike descriptions of the yeshiva as the bastion of anti-assimilation and anti-secularism, Hutner claims that this kind of institution is a necessary but ultimately temporary stage in one's religious growth. ${ }^{98}$ A student goes to yeshiva for a long period of time, especially in his youth, where he is molded and shaped by the religious educators and the fellow students alike.

Honing spiritual and scholastic skills and cultivating his inner work, the yeshiva provides a unique environment in which a student accomplishes these goals. This religious preparation then allows the individual to go out into the world and, like one who treads upon the sand, leave a sacred imprint upon that which had seemed mundane. This takes courage and, as in all aspects of life, failure is inevitable and unavoidable. ${ }^{99}$ Even great leaders will fail, and they have their own inner struggles. Interestingly, this inner struggle, the fact that the teacher is also in process and is not perfect, becomes part of their educational power, not contra to it. But the goal is to have courage and to strive for the ideal of bringing the holy into the ordinary, thus transforming the world outside of the yeshiva. ${ }^{100}$

We might think of Hutner's ideal yeshiva as a kind of educational enclave, following the work of Mary Douglas, defined as a social structure with a strong sense of boundaries: "Committed enclave members try to resolve the practical contradictions of either estate by erecting a wall of virtue between themselves and the outside world, a world they never cease to revile." 101 Douglas notes that the enclave is usually established "by a dissenting minority," becoming "a social unit which maintains a strong boundary but unlike the hierarchy it tends to be egalitarian ... [and] there is a distinctive culture of competitive individualism." ${ }^{102}$ But such descriptions do not fit Hutner's yeshiva at all, defined by the rigid hierarchy of the honor-driven master disciple relationship. Though he expresses trepidation at the "deluge of heresy and ignorance" outside of the yeshiva, the boundaries of the educational structure are temporary. The student goes out into the world that is to be transformed rather than reviled.

Drawing, rather, from the terms of cognitive anthropology and educational theory, we might do better to approach Hutner's vision of the yeshiva as "a community of practice" meant to train the student for the rest of his life. This socio-educational structure of this group is defined by Etienne Wenger as follows:

Being alive as human beings means that we are constantly engaged in the pursuit of enterprises of all kinds... As we define these enterprises and engage in their pursuit together, we interact with each other and with the world and we tune our relations with each other and with the world accordingly. In other words, we learn.

Over time this collective learning results in practices that reflect both the pursuit of our enterprises and the attendant social relations. These practices are; thus, the property of a kind of community created over time by the sustained pursuit of a shared enterprise. ${ }^{103}$

A community of practice reflects some of the broadest dimensions of human life: the quest for knowledge, development, and inter-connectivity. It is a voluntary association of individuals united by the single overlapping quest, one that is embodied and embedded and not purely intellective. The master or expert has an important place in this community as well "Teachers, masters, and specific

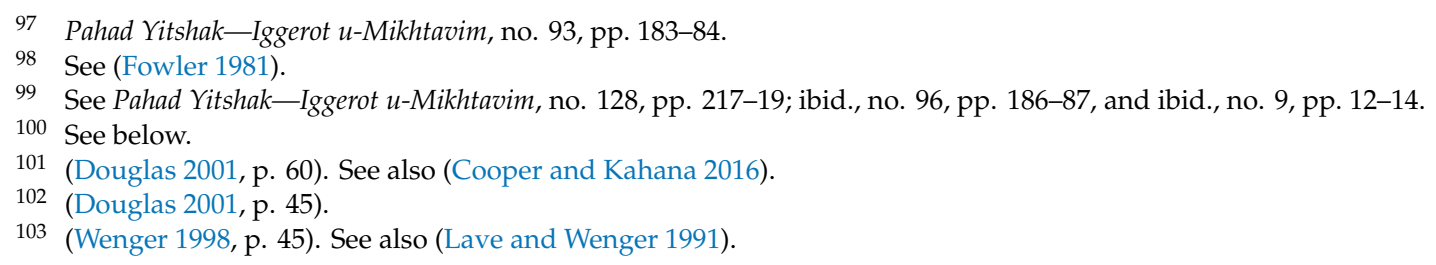


role models can be important," notes Wenger, "but it is by virtue of their membership in the community as a whole that they can play their roles." ${ }^{\prime 104}$ The educational power of the instructor derives from the fact that they, too, are insiders to the community and spiritual family.

This comparison between Hutner's yeshiva, a religious institution, and the community of practice, which is often conceived as a kind of third space, is imperfect. But I believe that it highlights something very important about his educational philosophy and the emphasis on consistent interactivity and shared superordinate goals of Hutner's yeshiva. His educational structure was a shared devotional environment in which the individual students have their own goals that complement and refract one another's, attempting to refine scholastic abilities and spiritual technologies for the sake of spiritual growth. Over the past several decades, theories of learning from the fields of anthropology, sociology, and education have underscored the extent to which cognition is situated in community and culture. Religious education and spiritual development do not and cannot happen in a vacuum. ${ }^{105}$ The place in which the student is embedded not only changes how he or she internalizes information and impacts the goals of the educational structure, but even what is valued or considered knowledge is a part of the social fabric, generated, interpreted, and embodied through social dimensions of life. ${ }^{106}$ Hutner's yeshiva, an Orthodox community of practice that is set aside from pedestrian life and serves as an intellectually and spiritually stimulating environment, both reflects cultural knowledge and constructs it at the very same time.

\section{Sacred Study and the Considered Life}

The cornerstone of Hutner's theory of religious education is the master-disciple relationship, a connection that is anchored and embedded in a community of practice. These bonds, with the teacher and with one's fellow travelers actively, shape everything about the process of education. But in some sense these relationships function as tools for the goal of religious education per se: Awakening the students to the power of the sacred text. Sacred study, for Hutner, is the centerpiece of religious education. Study requires focus; it is an all-consuming exercise that demands the totality of a person's attention. ${ }^{107}$ The emotive faculties are of importance, but it is an exercise of the mind that transforms the heart and soul. ${ }^{108}$ In particular, this means the discourse—and praxis—of studying Talmud. ${ }^{109}$

For Hutner, the goals of religious education and study include preserving a sacred tradition of knowledge that reflects Israel's covenant with God. The study of canonical texts continues the cultivation of a body of wisdom such that the knowledge may be passed on to the next generation. Hutner conceives of this as a separate duty that may be disambiguated from the obligation to pore over the words of Torah:

The Talmud in [tractate] Sotah, [folio] 37, explains that four covenants (beritot) were established upon each and every commandment: "to study, to teach, to protect, and to do." ... We may cite the explanation of the GRIZ [i.e., Rabbi Yitshak Ze'ev Soloveitchik, 1886-1959] ... who wrote that the covenant of "to keep" refers to the special obligation of protecting the received tradition (ha-kabbalah) that endures through us as it is passed down from generation to generation. This [injunction] is not included in the commandment to study and to teach, which refer to the study of Torah itself. There is a special religious obligation to protect the tradition and to pass it on to the generations. ${ }^{110}$

\footnotetext{
104 Wenger, Communities of Practice, p. 100.

105 (Brown et al. 1989; D'Ándrade 1981).

106 (Nardi 1996, pp. 69-102; and Lave 1993, pp. 3-32).

107 (Pahad Yitshak-Shavu'ot, ma'amar 9:1, p. 82. Thus, Hutner explains why a student is not allowed to ask a teacher about something other than the subject he is studying.

108 (Pahad Yitshak-Shavu'ot, ma'amar 15:5, pp. 97-98.

109 (Lehman and Kanarek 2011, pp. 581-96).

110 Pahad Yitshak-Shavu'ot, ma'amar 38:3, p. 210.
} 
Part of religious education is preserving a tradition, and this imperative that is above and beyond the injunctions to study. Of course, anchoring the educational enterprise in the need to pass on a religious or cultural patrimony is not a new argument. But Hutner's crafts his thesis in theological terms, reminding his readers-and listeners-that religious education must be grounded in the sacred covenant and reify its power. ${ }^{111} \mathrm{He}$ illustrates a meta-principle regarding the nature of scholarship that goes beyond the injunction to study and master the words of tradition. Religious education is transgenerational, theological, and performative; it is a quest that affirms community while reinforcing and recreating the bond between God and the people. Israel is charged with safeguarding the Oral Torah, an inherited body of discourse that is regenerated through continuous illuminated interpretation of its words, and then to pay it forward to the next generations.

Study; therefore, includes a permanent dialectic between innovation and revelation, between preservation and renewal. The discourse of Torah, argues Hutner, unfolds in both of these modalities. ${ }^{112}$ Certain moments are defined by a burst of newness and creativity, a pouring forth of new ideas never seen before. Other times are more about strengthening tradition and giving new vitality to threadbare ideas. Following tradition, Hutner maps these two modalities onto the theophany at Sinai and the story Purim, grounding theological narrative in the private life of the individual. He argues that sacred study demands both revolutionary inspiration and quiet renewal. Borrowing Hutner's idea, we might say that this obligation falls equally upon the teacher as well: In some cases, the teacher must provide illumination through true innovation. But other times, the master must do what is perhaps even harder: Through creative interpretation and the force of his religious personality, the teacher is charged with renewing the way his students look at familiar aspects of the self, the world, and the text. ${ }^{113}$

Such arguments about the sacral quality religious education go even further in Hutner's discourses. Study itself is described as a manner of coming to know God, a devotional practice that embodies what it means to love the Divine. ${ }^{114}$ Religious study is, for Hutner, an encounter with God in which the student or worshipper relives the moment of revelation at Sinai. It is not about preparing for a later event when one has attained the vistas of knowledge or scholarship:

There are many differences between Torah and the other commandments. One of these differences is the notion of education (hinukh). ${ }^{115}$ There is education for the [other] commandments, but there is not education for Torah. A father who brings a small child into the Sukkah does not fulfill the commandment of Sukkah, but rather the commandment of education. ${ }^{116}$

But a father that brings his small child into the study of Torah has fulfilled the obligation to study Torah. The lulav in the hand of a small child is no more than an object (heftsa) of education), but "Torah that Moses commanded us" of a small child ${ }^{117}$ who knows how to speak, this is an object of Torah itself. There is no education in study of Torah. They are the very same words. ${ }^{118}$

Classical rabbinic notions of educative instruction or religious habituation do not apply to the study of Torah, suggests Hutner, because study is itself an encounter with the Divine. Entering the words of

111 See (Goshen-Gottstein 2019, pp. 118-54).

112 Pahad Yitshak-Purim 3:4, p. 38. See also b. Shabbat 88a-b; (Scholem 1995, pp. 300-3; Halbertal 1997).

113 See (Heschel 1996, pp. 33-39).

114 Pahad Yitshak-Shavu'ot, ma'amar 18:9, pp. 132-33; and ibid., ma'amar 9:2, p. 82. In thinking of religious study as a praxis beyond scholarship and scholasticism, we would do well to recall the words of (Graham 1987, pp. 162-63): "Sacred books are not just authoritative documents or sources of doctrinal formals; they are living words that produce a variety of responses - emotional and physical as well as intellectual and spiritual. Moreover, at no point in the life of a sacred book is it likely to elicit more varied responses than when it is being chanted, sung, or recited in some meaningful context such as that of worship or meditation." See also (Davidson 1974, pp. 53-68).

115 See (Gilat 2015); idem, (Gilat 1995; Broyde 2016).

116 See the exploration of this them in (Weiss 2017).

117 Traditionally this is the first phrase, together with the Shema, that is recited by children as they learn to speak.

118 Pahad Yitshak-Hanukkah, ma'amar 11, pp. 98-99. 
Torah does not prepare one for something later. The encounter of the text is itself a fulfillment of the religious obligation to study, a commandment that has no limitations and is all-consuming. In other words, for children religious education is not about preparation for something down the line, but about being and becoming in the present moment.

Hutner's emphasis on the spiritual life of the child is not an incidental example for a greater principle. He notes that religious education is particularly important and effective for the youth, and his explanation as to why this is true is fascinating. "There is additional virtue," says Hutner, "in shouldering the yoke of Torah and the commandments when still in the period of one's youth."119 He explains that this is because one's childhood and youth is a period of tremendous and constant creativity. Or, better yet, childhood is a time of spiritual and physical transformation that mirrors the constant recreation of the cosmos itself:

Just as when the blessed Holy One spoke the first time "Let there be light", the light was a total innovation that was brought into existence from Nothing into Being (me-ayin el ha-yesh), so too does this utterance of "let there be light" continue to act at each and every moment, renewing the existence of light from nothingness into being. The sustaining of existence in this moment does not force it to be so in the next. Therefore, in the deepest sense, all of creation is filled with continuous renewal. ${ }^{120}$

The fabric of the cosmos is such that it is always being reinfused with divine energy. It is being verily recreated and conjured up from the infinite pool of potential-the Naught or Nothing-once more. The education of children, claims Hutner, must mirror the rhythm of this cosmic cycle:

A person, during the time of his youth, finds a similar process of creation in his body. His stature grows bigger and bigger. First he becomes a child, and then he becomes a youth. If this youth is wise, he will use this renewal in his body and make into a vessel of renewal of the soul.

Therefore, my beloved, it is good for one to shoulder the yoke in his youth. Do not think that you are taking upon yourself the yoke despite being a youth. We want your acceptance of Torah to come precisely because you are youths. The yeshiva asks you to your receiving of the yoke of Torah to be signed with the renewal of innovation ... ${ }^{121}$

The return to the Nothing and rebirth of the self as a different being is a theme well known in Hasidic sources. ${ }^{122}$ Here it is linked particularly to the stratospheric biological, physiological, and physical changes that come along with adolescence and puberty. Rather than an obstacle or a hinderance, Hutner claims that these transformations become fodder for spiritual growth and education.

The nexus of religion and youth culture has been well documented. ${ }^{123}$ In many cases this period of life is a time of rebellion and rule-breaking. Youth cultures often lead the way in societal transformation and religious changes, reflecting a gap in ideological and cultural distance between generations. ${ }^{124}$ Such was the case, for example, with early Hasidism in the eighteenth century, a religious movement born at least in part by intellectual and spiritual foment among the youth. ${ }^{125}$ Something of that ethos powered-and powers-Lithuanian yeshiva culture as well.

This connection between vulnerability, transformation, and spiritual capacity is true of children, and all the more so of adolescents. ${ }^{126}$ Entering a critical period for spiritual journeys and identity

\footnotetext{
119 Pahad Yitshak-Iggerot u-Mikhtavim, no. 74, pp. 134-35.

120 Pahad Yitshak-Iggerot u-Mikhtavim, no. 74, p. 135. See also (Berger 1983, pp. 107-28).

121 Pahad Yitshak-Iggerot u-Mikhtavim, no. 74, pp. 134-36

122 See (Mayse, forthcoming a).

123 See (Robbins et al. 1975; Hyde 1990; Collins-Mayo and Dandelion 2016; Giordan 2010).

124 (Geertz 2017, pp. 433-34; Jacobson 2006).

125 On Hasidism as a youth movement, see (Green 2013c; Dynner 2009, pp. 158-60, 175-81; Hundert 2004, pp. 179-95).

126 See (Shire 2011, pp. 301-18).
} 
formation, ${ }^{127}$ some adolescents find it to be a time of increased spiritual sensitivity and interest. Physiological and emotional changes, otherwise destabilizing and often still frightening, become agents of spiritual education. When educators-or parents-are alert to these massive transformations, it may create room for conversations about critical issues of faith during this time of change. ${ }^{128}$ Recalling the unique power of this period, Hutner demands a youth-centered approach to religious education.

Hutner argues that the educational environment—and, moreover, the very project of education - may be fueled by these embodied and inner transformations. He argues that transition and transformation are not radical breaks with the past, but rather the ever re-becoming of the world and the human self. They are, in short, the very definition of the cosmos. Identity formation and physical changes of the youth come to mirror and embody the cosmic cycles, turning them into tools for worship and spiritual growth. The correct environment and with the correct educational agenda become part of a key rite of passage, here construed not as an individual ritual but as a period of time spent in insensitive religious education among a communitas that then ushers the student into his later life. ${ }^{129}$

Like cultivating a deep master-disciple relationship or a sacred community of practice, this rich mode of sacred study is not the work of a moment. Scholarship is a journey that must be pursued at all times. Hutner actively discouraged days off, noting that even when schools are forced by law, children should be encouraged to come even if for a short while to maintain a sense of constancy. ${ }^{130}$ In this he makes psychological point about the educational value of consistency, but Hutner argues that constant religious study creates a sense of spiritual coherence that unites the sum totality of a life together. He notes that the verses from the book of Deuteronomy, recast in the Shema' prayer as a doxology of faith as well as an expression of praxis, demand that a worshipper speak about God's words at all times, teaching them to his children and discussing them when walking, when arising, getting up, and so forth. In addition to aiding recall, this has a greater purpose:

All moments and times of one's life are [thus] combined into a single structure through the study of Torah. And so, too, the next verse unites all generations of the life of the community of Israel into a single structure through the study of Torah.

But the place that the life of the person combines to a single structure of times and minutes is through the study of Torah itself. The life of the community of Israel is united into a single structure of the generations through the wise sage who teaches Torah to his students. ${ }^{131}$

The discourse of Torah includes two interrelated unitive properties, both of which shape the student's life. The first is that such focus in study links all the moments and times of one's life into a single, song-like expanse of moments that blend into a harmony. If one thinks of Torah at all moments, than rather than disparate incidents, all times are drawn together into a single arc or structure-much like the image of the points around the perimeter of the circle invoked above. The second quality of Torah is that it represents a kind of melodious conversation that stretches the generations. One generation is linked to the next through shared commitment to sacred study, to the shared exegesis of the same canon of sacred texts. In the words of contemporary educational theorist Parker Palmer:

Through the study of sacred texts, I maintain contact with the spiritual tradition, with the seeking and finding of those who have gone before. These texts allow me to return to times of deeper spiritual insight than my own, to recollect truths that my culture obscures, to have companions on the spiritual journey who, though long dead, may be more alive spiritually

127 (Good and Willoughby 2008); and cf. (Büssing et al. 2010).

128 See (Dollahite and Thatcher 2008).

129 See also (Turner 1977, esp. pp. 94-165; Venable 1997).

130 See (Carmy 1981, p. 226).

131 Pahad Yitshak-Shavu'ot, ma'amar 24:4, p. 157 
than many who are with me now. In such study my heart and mind are formed by the steady press of tradition against the distortions of my day. ${ }^{132}$

Religious study is part of meeting God, and it connects one to previous generations. Study Hutner's vision of religious education is a kind of spiritual journey of self-formation. At the heart of this temporal compresence, Hutner reminds us, is the teacher-the fulcra of religious education that stands at the origin of these two different axes.

Such religious education happened around the text of the Talmud in particular. Such was the tradition of Hutner's intellectual inheritance, so we could hardly expect him to do otherwise. But he seems to have been alert to the fact that many of his American students would not find Talmud to be an obvious subject for intensive spiritual and theological reflection. ${ }^{133}$ Hutner offers interesting and original reflections as to why the study of Talmud holds particular significance, and, of perhaps even greater importance, he sets limits on the Talmudic totalism of religious education.

The Talmud is an all-consuming text. ${ }^{134}$ In one discourse, Hutner cites the well-known Talmudic statement that one should divide time for study evenly: one third Hebrew Bible, one third Mishnah, and one third Talmud (i.e., Gemara). ${ }^{135}$ Hutner refers to the interpretation of the medieval Talmudist Rabbenu Tam, who says that the Babylonian Talmud (the Bavli) is thus named because all three elements-Scripture, Mishnah, and Talmud-are all mixed up (balul) in it. One can; therefore, fulfill one's total scholarship obligation without plying oneself to anything other than the Babylonian Talmud. Hutner accepts Rabbenu Tam's explanation but changes its axis significantly. He identifies two distinct elements of the study of Talmud (called hokhmat ha-Talmud). The first is knowing the reasons for the different practices and halakhot, and the second is the process of learning things from one another through creative analysis, comparison, taking things apart, and getting to the bottom of the matter. In most subjects, this is a secondary and higher-order process, one that comes after the foundation-stones of knowledge have been set into place through diligent study.

The Babylonian Talmud, argues Hutner, offers a textual intersection of the two approaches: "In our Talmud, these two parts of the wisdom of the Talmud are not divided from one another, with each in its own realm. Just the opposite: the two parts of the wisdom of Talmud are connected to one another and integrated in our Talmud."136 Memorization and reasoning are not two stages in scholarship, but two interrelated modes of study that necessarily coexist in the prepossessing dialectics of the Talmud. This feature, argues Hutner, is why it is called the Yam shel Talmud, the ever-unfolding sea of Talmudic wisdom. "Each and every one of its waves is bound up with the others, merging into the next one." 137 The Talmud is a multi-layered document filled with meandering argumentation, but it is also "a single piece of construction" that cultivates education on multiples planes. Talmud study generates wisdom and higher-order religious knowledge together with, and through, the forays and memorization and the more pedestrian elements of the educational project.

For this reason, all roads lead to the Talmud, in a certain sense. Hutner identifies a fascinating innovation lurking in the words of Maimonides in his reformulation of the above statement about dividing ones' time. All religious scholarship is, in some sense, a preparatory obligation (hekhser mitsvah) for the study of Talmud. Commenting on Maimonides' formulation that a mature scholar should "devote himself to talmud for the rest of his days, according to his breadth of mind and maturity of intellect," 138 Hutner suggests;

32 (Palmer 1993, pp. 17-18).

133 See also (Mayse 2018, pp. 369-409); and idem, (Mayse, forthcoming c).

134 See (Dolgopolski 2013).

135 See b. Kiddushin 30a.

136 Pahad Yitshak-Shavu'ot, ma'amar 28:3, p. 184

137 Pahad Yitshak-Shavu'ot, ma'amar 28:3, p. 185.

138 Mishneh Torah, hilkhot talmud torah 1:11-12; the italics represent the nuance of Maimonides' intent in employing the word talmud. My thanks to Professor Bernard Septimus for sharing his incomparable translation of this book. See also 
We distinguish between things that prepare for holiness and holiness itself. And so too, [we divide] between the preparatory acts for a commandment, and the commandment itself. Here, in the words of the Maimonides, we find that even among the corpus of the Torah itself, we find a relationship between preparations and the essential matters ... . The truest essence of Torah is only the study of Talmud; all processes of study are themselves like a pathway that brings one to this goal. This is a wondrous novum ... 139

Maimonides' has been reinterpreted here by Hutner in an fascinating and highly-creative manner, such that the medieval Andalusian sage has come to sound rather like the head of a Lithuanian Talmudic academy. All Torah study, he says, prepares you for the experience of Talmud, which brings the threads together and the study of which represents the pinnacle, the summum bonum, of all religious scholarship. Other subjects pave the way to penetrate its words. The Talmud weaves together all the strata of Jewish literature, and represents the fullest sense of what it means to come to understand God.

The emphasis remained on Talmud study in Hutner's yeshiva. There is; however, an interesting a tension on this front. Hutner is also well-known for having recommended that a student take up texts and subjects that he loves. In one, he refers to a case in which one has two sick people whom one should visit. It is up to the person, because the law does not tell him which to do. It is a matter of discretion in which one must follow the heart to know whom to visit. When it comes to what to study from within the ever-unfolding sea of Torah, such discretion is not an external principle plied to doubt but the very heart of what it means to come to know God through the text, the spiritual quest.

The study of Torah is different. Engagement with the place that his heart desires is the decision of the law itself. The explanation the matter is that all of the relationship of a person to the existence beyond himself is through connectivity (derekh hibbur). All of the senses perform their work through such connection. [For example,] the sense of touch (mihush) does its work through the connection in the power of touching (negiah) ...

It is impossible for the mind to come to any sort of understanding except through connection with the matter that is being grasped. This connection of the mind with its matter that is being grasped is effected through the power of pleasure that is hidden in this understanding. The power of the mind without the action of pleasure is like the power of the eye without the action of the light., or like the power of the ear without the action of the air ...

When the mind delights in understanding, this pleasure is the soul of the movement of understanding, without which the mind would remain like inanimate stone. Therefore, the heart's desire decides only in the study of Torah. In the commandment of studying Torah, increasing joy at the time of understanding necessarily results in an increase of understanding $\ldots 140$

The link between the knower and the known is not established through intellect alone, but through the emotive and embodied faculties of joy, delight, and desire. The erotic undertones of this are impossible to miss, perhaps also a reflection of the fact that he is speaking to an audience of young men, many of whom were unmarried. ${ }^{141}$ Joy forms the connection between the thing that is outside and what is inside, and pleasure ( $t a^{\prime} a n u g$ ) leads to deeper understanding. Hutner's vision is a far cry from the Aristotelian linkage between object and knower, nor the language of the Maimonides on this front or his various interpreters in the Hasidic canon. ${ }^{142}$

(Twersky 1967, pp. 106-18); (Twersky 1980, pp. 493-95). Cf. Maimonides' comments on m. Avot 2:4. See also Mishneh Torah, hilkhot talmud torah 3:7.

139 Pahad Yitshak-Shavu'ot, ma'amar 17:1, p. 122.

140 See also Pahad Yitshak-Shav' 'ot, ma'amar 15:6, pp. 98-99.

141 (Boyarin 1993).

142 See also (Wolfson 1965; Lobel 2002; Blumenthal 2014, pp. 85-109; Black 1999; Idel 2015, pp. 177-210). 
Hutner's vision also puts forward a fascinating epistemology in which religious education is an essential encounter founded in love and joy, one that that moves beyond Cartesian or Newtonian theories of knowledge. His re-envisioning holds implications for the teacher and student, as well and for pedagogy, centering the craft of education and self-formation on qualities of love that are expressed by and constructed through embodied practices. ${ }^{143}$ Hutner's devotional approach recalls the point made with such felicity by Michael Polanyi, who notes that our claim to "read or listen to a text, and ... not merely see it or hear it, is precisely to imply that we are attending focally to what is indicated by the words seen or heard and not to these words themselves." ${ }^{144}$ Cultivating love for the subject, and also knowing how to direct them to find this connection with the text. Literally coming to touch its essence, and, in doing so, to allow the text to touch them.

Talmud study has pride of place in Hutner's vision, but his relationship to the study of rabbinic literature being complemented by the heart's desire is different, for example, than that of Rabbi Avraham Yesha'yahu Karelits (1878-1953), another important scion of the Lithuanian Talmud world. Karelits's formulation of ahavat ha-din and ha-mishpatim, of love of the law and its study. This emphasis includes an important overtone of submission to the law and to the divine values it expresses. In short, the ego is destroyed in the confrontation with the text. ${ }^{145}$ Karelits writes: "the essence of healing these machinations of the soul is the study of halakhah, finely examining all of the details of its branches until love of the law is totally rooted in one's midst."146 For Karalits, study has a profound transformative effect meant to improve the soul, but it applies to nothing other than the examination of halakhah. Hutner's vision of study is filled with and indeed predicated upon the reader's t $a^{\prime} a n u g$ - meaning joy, pleasure, and self-directed delight-could be Talmud and halakhah, but it could be anything else as well: Bible, Midrash, even the literatures of Jewish mysticism-anything within the traditional canon and the ever-expanding and unfolding rubric of the Oral Torah.

Finally, for Hutner, the project of education stands upon the life of what you do. He frequently reminds his readers-and listeners-that all religious studies must be in order "to do" - that is, to perform the commandments and thus actualize the knowledge through religious deeds and ethical performance. ${ }^{147}$ The commandments have a miraculous qualities, says, Hutner, which produces a state of wonder and empowerment. ${ }^{148}$ Knowledge is; thus, integrated through the pathways of praxis, and this step is part and parcel of what may be attained through religious education. ${ }^{149}$ Through performing the commandments, one grafts theology and ideology to practice, thus linking the intellectual component of religious education to ritual performance. The commandments reveal the degree to which one has internalized the values of the Torah. ${ }^{150}$

There is an element of orthopraxis in this vision. Hutner laudatorily quotes the rabbinic teaching: "One whose acts are greater than his wisdom, his wisdom endures." 151 Even without full knowledge, you can indeed receive reward and open up the door for something deeper. ${ }^{152}$ Why? Because that is the very fundament of what they are. The commandments are bound to the Torah, and you cannot have one without the other. The revelation at Sinai was fundamentally a moment of unity of God and Israel. ${ }^{153}$ The commandments are reflections of the covenant, and, moreover, as the defining

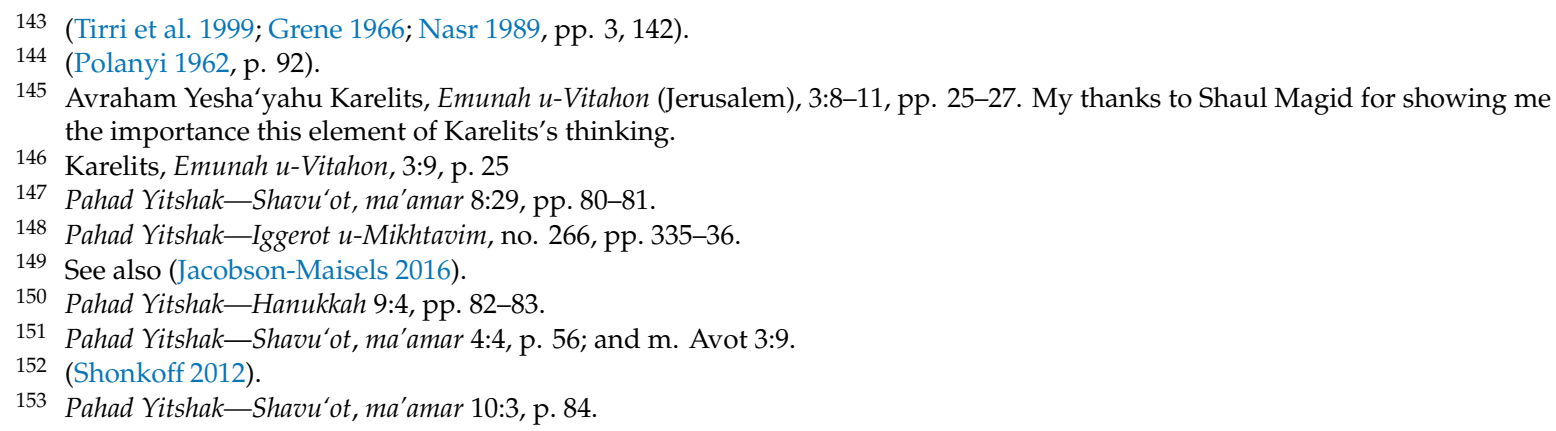


feature of revelation and its enduring relevance, a covenant of unity built out of deeds necessitated by involvement in both sides. ${ }^{154}$

Hutner then adds a fascinating aspect to his treatment of the commandments: They represent a modality of self-creation. He quotes the rabbinic teaching: "'Observe the words of this covenant, and do them' (Deut. 29:8)—read 'and do them (otam)' as 'and you shall fashion yourself (atem)'."155 Hutner then adds something quintessentially new:

Through observing the words of the covenant, it is considered as if the Jewish people create their own essential personhood ('etsem ishiyutam), and not like a person who conquers points that are found beyond the perimeter of his own essence. Only through the commandments are Israel are considered members of the covenant; only by keeping them do they create themselves. ${ }^{156}$

Observance of the commandments is essential to the religious life and to religious education. It is not about the mystical ecstasy or Kabbalistic theurgy, but neither does Hutner advocate for a kind of orthopraxis or even just pure obedience and submission. It is participatory model, in a sense, because the self-creation described herein comes through active engagement with the life of the spirit. ${ }^{157}$ For this reason, notions of transformative education - of education as an ongoing process of self-formation and perspectival shift tied to broader experiences-may provide us with a helpful model for thinking about his conception of the commandments. ${ }^{158}$

On final issue deserves treatment here, and that is Hutner's particular understanding of the way in which study seeps into everything because it changes the way you relate to the commandments. He very often notes that study is defined by being in order "to do"159, although these two-studying and doing-reflect very different religious experiences. ${ }^{160}$ But Hutner also argues that performance of religious deeds, as it were, retroactively links Torah study to everything. ${ }^{161}$ In making this point he picks upon a curious formulation in Maimonides' laws of Torah stud: "If the commandment can be performed by others, he should not interrupt his study; if it cannot, he should perform the commandment, then return to his Torah [study]. ${ }^{162}$ Does it not seem obvious that one would return to the study afterward? This addition begs explanation, and Hutner supplies it with force:

Indeed, it is explicitly noted in the Talmud that, in regard to Torah study, its interruption may [at times] be its fulfillment ${ }^{163}$... RaSHI explains that we have established that we interrupt Torah study for bringing in the bride. We have said that its interruption [i.e. of Torah] is its fundament and fulfillment. That is, one receives reward [for the interruption] as if he were [still] sitting, firmly established and immersed in it ...

The matter is simple. We have said that its interruption is its fulfillment, this is precisely when one interrupts his study for the sake of fulfilling the commandment of marrying off a bride or of taking out a body [for burial], or the like. If he interrupts his studies for a discretionary matter, or just for the sake of interruption, and he goes and fulfills the commandment of bringing in a bride or bringing out the dead, this is only the reward of the commandment but not that of the Torah, since he did not fulfil the commandment from amid the break in his

\footnotetext{
154 Pahad Yitshak-Shavu'ot, ma'amar 10:5, p. 85.

155 b. Sanhedrin 9b. See also (Hartman 2003).

156 Pahad Yitshak-Shavu'ot, ma'amar 10:3, p. 86

157 See (Green 2015; Sagi 2008, pp. 135-54; Benyamini 2015; Kasher 1994; Benbassat 2015; Ben-Pazi 2016). See also (Maayan 2017).

158 (Mezirow 1991; and O'Sullivan 2003).

159 Yitshak Hutner, Pahad Yitshak-Sha'ar le-Hodesh ha-Aviv (Brooklyn: Ha-Mossad Gur Aryeh, 1993), no. 68:3; and Pahad Yitshak-Shavu'ot, ma'amar 8:29, p. 80.

160 See Pahad Yitshak-Shavu'ot, ma'amar 24:2, on Torah as an all-consuming song.

161 See the reflections of (Carmy 1981, p. 219).

162 Mishneh Torah, hilkhot talmud torah 3:3. I extend my thanks once more to Professor Septimus.

163 b. Menahot 99b.
} 
studies for the sake of this. This is why Maimonides adds at the end of this halakhah: "then return to his study" - that is, because he returns to his studies immediately after fulfilling the commandment, he establishes that the interruption in his study was only for the sake of this commandment.

Through the power of this establishment (i.e., that one stopped only for a religious purpose), his performance of the commandment is arranged retroactively and the deed is situated within [the category of] "its interruption is its fulfillment." In this way, through returning to his study, he receives reward for study as well as for the commandment. ${ }^{164}$

Attuned study that is interspersed with a religious action produces an uninterrupted durée of devotion. The performance of the sacred deed is part and parcel of the project. Folded into the ultimate goal of religious life, which is Torah study. This means that the commandments can be fulfilled on their own terms, as actions or obligations mandated by the divine will, but they have an additional educative function as well: sacred deeds are a fulfillment of the expansively defined imperative to study Torah. ${ }^{165}$

An interruption of study in order to fulfill the text means that it too is filled with meaning. Even, in some cases, ordinary deeds. Hutner quotes the Talmudic tradition that God keeps the commandments, ${ }^{166}$ and then asks the question: How does God fulfill the commandment of "know Him in all your ways" (Prov. 3:6), of knowing the divine through everything? ${ }^{167}$ Discretionary acts (divrei reshut) are neither demanded by religious obligation nor forbidden. To explain this intermediate zone, Hutner draws a parallel to the concept of revealed miracles and hidden miracles. Revealed miracles, like the Exodus from Egypt, are like God performing the commandments—explicitly, clearly, obviously, immediately. Hidden miracles are those that transpire through a concatenation of circumstances; the actors are not always clear, nor is the divine hand eminently visible. These quiet processes, garbed in this-worldly events, are akin to our serving God through the physical world, corporeality, physicality. One of the foremost goals of religious education, claims Hutner, is to awaken the student to the reality that there are no ordinary or mundane deeds in the sense of being cut off from the religious life. As he reminded the pensive student concerned with a career outside of yeshiva, one must grow the life to become "broad" - to become an expansive vista of devotion in which study becomes an act of self-creation and in which the world is drawn together by a unitive vision of God. ${ }^{168}$

\section{Reflective Conclusions}

Thus far we have explored Hutner's educational vision and pedagogical theory, interrogating the nature of the master-disciple relationship, the community of seekers, and the notion of sacred study as infusing life with new layers of meaning and power. In closing, I wish to consider what Hutner's teachings on religious education and learning have to contribute to today's broader culture and the challenges facing contemporary education. Such reflections require me to step out from beyond the authorial curtain and break the fourth wall. I speak as a situated educator embedded within several different communities, and these have shaped my understanding of Hutner's writings and their contemporary relevance. ${ }^{169}$

Over the past decade, I have had the pleasure of teaching Hasidic thought and theology in a wide range of education institutions including American and Israeli yeshivot, the rabbinical school of Hebrew College, and, at present, Stanford University. These various educational environments have

\footnotetext{
164 Pahad Yitshak—Shavu'ot, ma'amar 40:6, pp. 217-18.

165 Pahad Yitshak-Shavu'ot, ma'amar 40:7, p. 218.

166 Yitshak Hutner, Pahad Yitshak—Purim (Brooklyn: Ha-Mossad Gur Aryeh, 1989), no. 10, p. 51, commenting on b. Berakhot $6 a$.

167 (Kauffman 2009).

168 (Seligman et al. 2008, p. 180), argues that: "ritual is something that is happening to some extent all the time, in the most seemingly common, mundane aspects of our lives."

169 An alternate version of these remarks, addressed to a very different audience, may be found in (Mayse, forthcoming d).
} 
provided very different opportunities and challenges; each have shaped my approach to reading-and teaching-Jewish sources and have guided the questions that drove forth my interpretation thereof. ${ }^{170}$ Personal spiritual reflection, for example, is a welcome and even necessary component of education in the yeshiva or rabbinical school.

There, in Jewish academies of learning of various kinds, my investigation of Jewish texts emphasized how the sources might inform our own lives of prayer or spark inner spiritual growth, considering how the sermons shape and challenge our personal theology. As a rabbi as well as an historian, in such religious settings I speak-and interpret texts-as one who inhabits a discourse shared with the students. We are all part of the same community of spiritual seekers, although our assumptions regarding everything from the nature of God to the idea of religious practice may differ in profound ways. Together we examine Jewish sources from within the tradition, allowing their wisdom to make claims of us and to inform our spiritual world.

My current teaching; however, focuses on undergraduate and graduate education in a department of Religious Studies at a secular university. I should say that this primary institutional home-working within a Religious Studies milieu rather than Jewish Studies-has exerted a formative and very positive influence on my thinking and teaching. Most of my faculty colleagues work on subjects that are quite distant from the specific questions or materials that I work on. though they care very much about the core issues and deeper questions of history, meaning, and theology—and theory. In hallway conversations and department colloquia alike, I find myself forced to explain why the subjects of my research and teaching are so important for students of religion, and how they can better help us understand broader issues of the human spirit and devotion. Moreover, my colleagues have expanded my thinking on the nature of religious education across various faith traditions, awareness that has enriched my scholarship and shaped my performance in the classroom.

Only a small number of my undergraduate students at Stanford come with any significant backgrounds in Jewish learning, though some have taken classes in Jewish or Religious Studies. Few have the language skills necessary to engage with the Jewish texts in the original language with any degree of fluency. Teaching religious sources in this setting requires me to make the often-recondite ideas accessible to students without many years of preparatory study. Since many of my students are not Jewish, this environment also demands that I help individuals find academic and personal meaning in an array of sources from a faith tradition and religious discourse other than their own.

The reasons that bring such individuals to enroll in my courses and the questions that inform our discussions differ from those of gap-year yeshiva students and future rabbis, but many university students are driven by questions of meaning as well. What does it mean to be a good person, my Stanford students ask, and what is the relationship between authority, personal authenticity, and "disruptive" or rebellious thinking? Though interested in the interface of morality, religion, and progressive values within the humanities, Stanford students are also deeply concerned with the core questions of STEM disciplines: Is consciousness no more than a projection of material reality? What is the nature of the self? Can science reveal everything there is to know? How do we go about constructing a life of meaning in the age of technology?

Reading religious texts at a secular university requires me to do so as a humanist, as an intellectual historian with a keen interest in these enduring questions of existential meaning. This point raises; however, one of the essential issues that I face in my American university classroom: What do these teachings, most of which were generated in the small towns of Eastern Europe, have to offer the discourse of the humanities? To the moral, political, and environmental crises of our day? That Stanford is a major research institution without a divinity school amplifies the need for its humanities faculty to make space for moral and philosophical exploration as part of its liberal education. ${ }^{171}$ Our classrooms must,

\footnotetext{
170 See the essays in (Levisohn and Fendrick 2013; Kanarek and Lehman 2016).

171 See (Blumberg 2018).
} 
I believe, provide students with a home for a kind of sustained spiritual reflection that complements their intellectual development. Religious texts serve as a vital resource to our students in their quest for self-formation. ${ }^{172}$

Hutner's view of spiritual education also gives a way of thinking about the foundational question: What makes Jewish teaching or learning "religious"? The categorical term "religion" is one that cannot be comfortably applied to the Jewish literary and spiritual tradition, ${ }^{173}$ but, in this case, Hutner's writings have much to offer contemporary debates on this issue. Certain resonances of these qualities may be found in other religious traditions, including the lectio divina practices of Christianity and the traditions of sapiential exegesis of Islam, ${ }^{174}$ as well as in humanistic visions of education from the Renaissance and Enlightenment to the present day. Hutner's writings; however, bring together a variety of insights into a remarkable vision of religious education.

This question returns us once more to the four core themes of the article. The first is that religious education hinges upon the unique master-disciple relationship. This bond, which is intense, intimate, fraught with complexity, and yet incomparably powerful, is the backbone of religious education. A second quality that defines one's education as religious is the conscious attempt to fuse creative engagement with a particular mimetic and textual tradition -with a body of discourse stretching across generations-with reflective goals of self-formation, inner transformation, and spiritual illumination. The third attribute of religious education, obviously related to the three previous qualities, is that scholarship necessarily includes a theological component. The journey into the text, undertaken under the tutelage of a master and begun while ensconced in a community of practice, is essentially a quest to know the One through the veils of human language. Finally, religious education demands action and activity. Rather than ivory-tower intellectualism or the pious quest of the spiritual ascetic, Hutner argues that religious awakenings and the quest for God demand that the student-and the teacher-go out and impress a positive imprint upon the broader world. Like a beachcomber whose tread leaves footsteps upon the sand, religious education demands that one walk through the world as an agent of holiness, spiritual sensitivity, and compassion.

Let us drill into these themes a bit more deeply. Hutner's vision of the master and disciple, a relationship founded in honor, respect, and mutual love provides a very important example for thinking about the role of the teacher in higher education. University life has become increasingly informal, something I have noted in the two decades I have been involved in it. ${ }^{175}$ Friendship with students has its place, but it also has its costs. In many instances the few remaining boundaries are artificial, barring, and preventing authentic interpersonal engagement while simultaneously jettisoning any sense of reverence for the teacher as a voice of wisdom. The university professor, like Hutner's ideal rosh yeshiva, is charged with translating the tradition for the students, bringing them into a new body of literature and giving them the linguistic, historical, and conceptual tools to understand it, but also to grant them the keys to the kingdom in becoming active participants and interpreters in the conversation across the generations.

The balance between these poles is not easy. Shalom Carmy notes in his analysis of Hutner's educational message: "To make personal the relation between teacher and student depends less on the fealty to some romantic critique than on the intellectual and emotional resources of the teacher and the students. ${ }^{176}$ It demands respect, courage, and, at the end of the day, mutual love. Dreadful misuses of power are all too well known in religious and higher education. Despite the problems, I find inspiration in Abraham Joshua Heschel's words:

\footnotetext{
172 See (Aldama 2008; Fynsk 2004, esp. pp. 41-76).

173 See (Batnitzky 2011); and see also Martin Buber's distinction between "religion" and "religiosity" in (Buber 1967, p. 80); and idem, (Buber 2016, p. 3).

174 (Hall 1988; Robertson 2011; Nasr 1989).

175 See (Hemer 2012).

176 (Carmy 1981, p. 218).
} 
Everything depends on the person who stands in the front of the classroom. The teacher is not an automatic fountain from which intellectual beverages may be obtained. He is either a witness or a stranger. To guide a pupil into the promised land, he must have been there himself. When asking himself: Do I stand for what I teach? Do I believe what I say? he must be able to answer in the affirmative.

What we need more than anything else is not textbooks but textpeople. It is the personality of the teacher which is the text that the pupils read; the text that they will never forget. ${ }^{177}$

It is an idea that I firmly embrace. Here Jewish wisdom joins with that of the religious traditions across the world, which have a unique model of the master-disciple relationships at their core. ${ }^{178}$ There is something really important in Hutner's vision of the spiritual educator for our world as well.

The image of the educator as a life-giver and parent, evoked with such tender pathos in Hutner's writings and addresses, is one laden with moral responsibility. I recognize fully that in loco parentis is complicated indeed, and that it can have negative impact as well as positive. ${ }^{179}$ Hiding ourselves from that fact is definitely problematic. Some years back, Virginia Worley argued that "recognizing in loco parentis as a transformative location and teachers as agents of change at that location helps one understand how schools' and teachers' in loco parentis charge becomes a means for inciting positive change." ${ }^{\prime 180}$ In loco parents has its hazards, and power dynamics have pitfalls. But education is, after all, a dangerous game, and all those involved are playing for keeps. ${ }^{181}$

With the notion that transformative religious education happens best in the context of community rather than isolated minds. Students, like faculty, should be encouraged to teach one another. ${ }^{182}$ For this reason, I run my classes as conversationally as possible, without allowing the arc or trajectory to drift, and I try to get students to engage with one another. Bonding over texts and ideas, over intellectual and spiritual struggles, they become each other's teachers and fellow-travelers in stepping out from beyond the screens of social media and electronic communication.

The model of Torah study advanced by Hutner demands assiduousness, consistency, and investment. Engaging with the principles behind the Slow Food movement, Maggie Berg and Barbara K. Seeber have argued that "Slow Professors act with purpose, taking the time for deliberation, reflection, and dialogue, cultivating emotional and intellectual resilience ... "183 Moving away from the frenetic speed of academic life and toward a pace that prioritizes engagement and depth, I often pause when teaching, giving students the time to reflect on the sources and to become keenly attuned to the silence between the words of the text rather than being content to gaze upon its surface. ${ }^{184}$ Education as self-construction must be a slow and focused process, and silence may become a crucial tool for teaching students to think for themselves, to formulate their own questions, to conjure up new meaning from ancient texts, and to open their hearts and minds to the power of these sources.

In the quest for scholarship, one must allow the ideas to seep in, to nurture and change you. This requires a posture of reverence of the sources of wisdom. In more direct terms, Hutner's notions of kavod ha-Torah offer an antidote to unchecked skepticism, hermeneutics of suspicion, and literary deconstruction without any attempt to re-construct meaning in the wake of textual dismantling. ${ }^{185}$ When translated into the world of contemporary academia, Hutner's vision does not

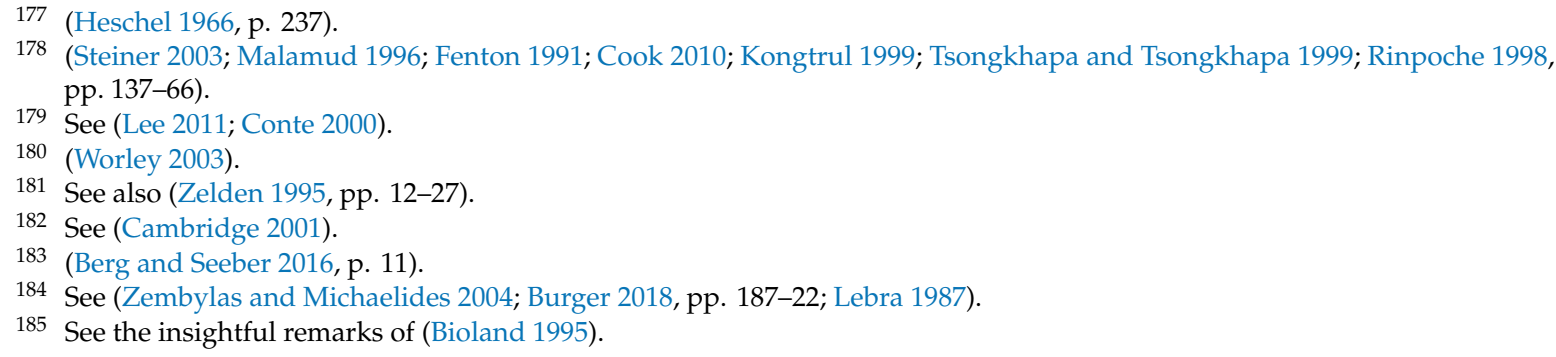


mean unwillingness to critique, to use critical methods to understand them. The texts make claims, some of them normative and prescriptive when it comes to ethics. We struggle with them. In the end we may not agree with them, but neither should they be immediately dismissed.

This vision changes the quality of one's study, deepening the way that one engages with texts and shaping the ultimate goal of this engagement. Rather than scholastic or sophistic enterprise, study; thus, becomes the cultivation of sapiential knowledge and wisdom. As Seyyed Hossein Nasr has argued:

Without reviving spiritual exegesis, it is not possible to rediscover scientia sacra in the bosom of a tradition dominated by the presence of sacred scripture. Scripture possess an inner dimension which is attainable only through intellection operating within a traditional framework and which alone is able to solve certain apparent contradictions and riddles in sacred texts. Once intellectual intuiting becomes inoperative and the mind a frozen lake over which ideas glide but into which nothing penetrates, then the revealed text also veils its inner dimension and spiritual exegesis becomes reduced to archeology and philology. ${ }^{186}$

Nasr's warning regarding the arid qualities of hyper-critical academic study without a devotional underlay extends far beyond the teaching of religious texts within a parochial educational context. He reminds us that study should be an act of moral reckoning, one in which the student or teacher must pierce beyond the surface of the text and dive into the ideational and philosophical core.

Finally, Hutner's vision reminds us that what we learn should ideally shape the ways that we move in the world. "Doing' is a precondition of study," writes Hutner. Religious education-as with liberal education in the university setting-should lead to more self-reflective, moral, compassionate, and ennobled behavior. It should grant us the courage to act in the world in new ways. "A Jew is asked to take a leap of action rather than a leap of thought," writes Heschel. "He is asked to do more than he understands in order to understand more than he does. In carrying out the word of the Torah he is ushered into the presence of spiritual meaning." 187 For most of my students this does not mean observance of the classical Jewish commandments, but rather a sense of deepened moral engagement grounded in action, of obligation toward others expressed not only in inner sentiment but in deeds of compassion and caring. Hutner's message of the power of religious education is ever-resonant and increasingly needed in our current world, a realm in which the values of integrity, sincerity, and moral responsibility are increasingly evacuated from civic and educational life.

Conflicts of Interest: The author declares no conflict of interest.

\section{References}

Aberbach, M. 1967. The Relations Between Master and Disciple in the Talmudic Age. In Essays Presented to Chief Rabbi Israel Brodie. Edited by H. J. Zimmels, J. Rabbinowitz and I. Finestein. London: Soncino.

Abrahamov, Tsippi. 2000. Correction or Creation? The Idea of Repentance in the Thought of Rabbi Isaac Hutner. Daat: A Journal of Jewish Philosophy and Kabbalah 44: 95-122. (In Hebrew)

Abrams, Daniel. 1996. Orality in the Kabbalistic School of Nahmanides: Preserving and Interpreting Esoteric Traditions and Texts. Jewish Studies Quarterly 3: 85-102. [CrossRef]

Aldama, Frederick Luis. 2008. Why the Humanities Matter: A Commonsense Approach. Austin: University of Texas Press. Anderson, John R., Lynne M. Reder, and Herbert A. Simon. 1996. Situated Learning and Education. Educational Researcher 25: 5-11. [CrossRef]

Assis, Elie. 2004. Divine Versus Human Leadership: An Examination of Joshua's Succession. In Saints and Role Models in Judaism and Christianity. Edited by Marcel Poorthuis and Joshua Schwartz. Leiden and Boston: Brill. Bashevkin, Dovid. 2016. Letters of Love and Rebuke from Rav Yitzchok Hutner. Tablet Magazine, October 10.

186 (Nasr 1989, p. 149).

187 (Heschel 1976, p. 283). 
Batnitzky, Leora. 2011. How Judaism Became a Religion. Princeton: Princeton University Press.

Benbassat, Roi. 2015. Yeshayahu Leibowitz: Jewish Existentialism. Religious Studies 51: 141-63. [CrossRef]

Benjamin, Mara H. 2018. The Obligated Self: Maternal Subjectivity and Jewish Thought. Bloomington: Indiana University Press.

Ben-Menahem, Hanina. 2008. Two Talmudic Understandings of the Dictum 'Appoint for Yourself a Teacher'. In Thinking Impossibilities: The Intellectual Legacy of Amos Funkenstein. Edited by Robert S. Westman and David Biale. Toronto: University of Toronto Press.

Ben-Pazi, Hanoch. 2016. Theodicy as the Justified Demands of Atheism: Yeshayahu Leibowitz Versus Emmanuel Levinas. Modern Judaism 36: 249-76. [CrossRef]

Benyamini, Itzhak. 2015. On the Self-Creation of God: A Critical Theology of the First Verses of Genesis, Following Leibowitz and Hegel. The Bible and Critical Theory 11: 1-20.

Berg, Maggie, and Barbara K. Seeber. 2016. The Slow Professor: Challenging the Culture of Speed in the Academy. Toronto: University of Toronto Press.

Berger, David. 1983. Miracles and the Natural Order in Nahmanides. In Rabbi Moses Nahmanides (Radmban): Explorations in His Religious and Literary Virtuosity. Edited by Isadore Twersky. Cambridge: Harvard University Press.

Biale, David, David Assaf, Benjamin Brown, Uriel Gellman, Samuel Heilman, Moshe Rosman, Gadi Sagiv, Marcin Wodziński, and Arthur Green. 2018. Hasidism: A New History. Princeton: Princeton University Press.

Bialik, Hayim Nahman, and Yohoshua Hana Ravnitzky. 1992. The Book of Legends [Sefer ha-Aggadah]. Translated by William G. Braude. New York: Shocken Books.

Bioland, Harland G. 1995. Postmodernism and Higher Education. The Journal of Higher Education 66: 521-59. [CrossRef]

Black, Deborah L. 1999. Conjunction and the Identity of Knower and Known in Averroes. American Catholic Philosophical Quarterly 73: 159-84. [CrossRef]

Blidstein, Gerald. 1975. Honor Thy Father and Mother: Filial Responsibility in Jewish Law and Ethics. New York: Ktav.

Blumberg, Ilana. 2018. Open Your Hand: Teaching as a Jew, Teaching as an American. New Brunswick: Rutgers University Press.

Blumenthal, David R. 2014. Maimonides' Philosophic Mysticism. In David R. Blumenthal: Living with God and Humanity. Edited by Hava Tirosh-Samuelson and Aaron Hughes. Leiden: Brill.

Bonner, Stanley F. 1977. Education in Ancient Rome: From the Elder Cato to the Younger Pliny. Berkeley and Los Angles: University of California Press.

Boyarin, Daniel. 1993. Carnal Israel: Reading Sex in Talmudic Culture. Berkeley: University of California Press.

Brown, John Seely, Allan Collins, and Paul Duguid. 1989. Situated Cognition and the Culture of Learning. Educational Researcher 18: 32-42. [CrossRef]

Broyde, Michael J. 2016. Why Educate?: A Jewish Law Perspective. Journal of Catholic Legal Studies 44: 179-94.

Buber, Martin. 1967. Jewish Religiosity. In On Judaism. Edited by Nahum N. Glatzer. Translated by E. Jospe. New York: Schocken Books.

Buber, Martin. 2016. Hasidism and Modern Man. Translated by Maurice Friedman. Princeton and Oxford: Princeton University Press.

Burger, Ariel. 2018. Witness: Lessons from Elie Wiesel's Classroom. Boston and New York: Houghton Mifflin Harcourt. Büssing, Arndt, Axel Föller-Mancini, Jennifer Gidley, and Peter Heusser. 2010. Aspects of Spirituality in Adolescents. International Journal of Children's Spirituality 15: 25-44. [CrossRef]

Cambridge, Barbara L. 2001. Fostering the Scholarship of Teaching and Learning: Communities of Practice. To Improve the Academy 19: 3-16. [CrossRef]

Carmy, Shalom. 1981. Rav Yitzhak Hutner's Lecture to a Teacher's Conference. Tradition: A Journal of Orthodox Jewish Thought 19: 218-226.

Cohen, Jonathan, and Elie Holzer, eds. 2008-2009. Models of Educational Transformation. Jerusalem: The Hebrew University Magnes, Press.

Collins-Mayo, Sylvia, and Pink Dandelion, eds. 2016. Religion and Youth. Brookfield: Taylor and Francis.

Conte, Anthony E. 2000. In Loco Parentis: Alive and Well. Education 121: 195-200.

Cook, Bradley J. 2010. Classical Foundations of Islamic Educational Thought. Provo: Brigham University Press.

Cooper, Levi. 2010. Technology Upgrading Teachers. Jewish Educational Leadership 9: 58-63. 
Cooper, Levi. 2018. Legislation for Education: Rabbi Tsevi Elimelekh of Dynów's Regulations for the Support of Torah in Munkács. Polin Studies in Polish Jewry 30: 43-72.

Cooper, Levi, and Maoz Kahana. 2016. The Legal Pluralism of an Enclave Society: The Case of Munkatch Hasidism. The Journal of Legal Pluralism and Unofficial Law 48: 75-91. [CrossRef]

Corrington, Gail Paterson. 1989. The Milk of Salvation: Redemption by the Mother in Late Antiquity and Early Christianity. Harvard Theological Review 82: 393-420.

D'Andrade, Roy Goodwin. 1981. The Cultural Part of Cognition. Cognitive Science 5: 179-95. [CrossRef]

Dalfin, Chaim. 2019. Rabbi Hutner and Rebbe. New York: Jewish Enrichment Press.

Davidson, Herbert A. 1974. The Study of Philosophy as a Religious Obligation. In Religion in a Religious Age. Edited by S. D. Goitein. Cambridge: Association for Jewish Studies.

Demetrakopoulos, Stephanie. 1982. The Nursing Mother and Feminine Metaphysics: An Essay on Embodiment. Soundings: An Interdisciplinary Journal 65: 430-43.

Dolgopolski, Sergey. 2013. The Open Past: Subjectivity and Remembering in the Talmud: Subjectivity and Remembering in the Talmud. New York: Fordham University Press.

Dollahite, David C., and Jennifer Y. Thatcher. 2008. Talking about Religion: How Highly Religious Youth and Parents Discuss their Faith. Journal of Adolescent Research 23: 611-41. [CrossRef]

Douglas, Mary. 2001. In the Wilderness: The Doctrine of Defilement in the Book of Numbers. Oxford: Oxford University Press.

Dynner, Glenn. 2009. Men of Silk: The Hasidic Conquest of Polish Jewish Society. New York and Oxford: Oxford University Press.

Efros, Israel Isaac. 1916. The Problem of Space in Jewish Mediaeval Philosophy: Chapter II. Absolute Space. The Jewish Quarterly Review 7: 61-87. [CrossRef]

Elman, Yaakov, and Israel Gershoni. 2000. Transmitting Jewish Traditions: Orality, Textuality and Cultural Diffusion. New Haven and London: Yale University Press.

Elman, Yaakov. 2014. Autonomy and its Discontents; A Meditation on the Pahad Yitshak. Tradition: A Journal of Orthodox Jewish Thought 47: 7-40.

Elman, Yaakov. 2015. Pahad Yitzhak: A Joyful Song of Affirmation. Hakirah; The Flatbush Journal of Jewish Law and Thought 20: 25-64.

Elman, Yaakov. 2017. Rav Isaac Hutner's Pahad Yitzhak: A Torah Map of the Human Mind and Psyche in Changing Times. In Books of the People: Revisiting Classic Works of Jewish Thought. Edited by Stuart W. Halpern. Jerusalem: Maggid Books.

Englander, Yakir Yacov. 2016. The 'Jewish Knight' of Slobodka: Honor Culture and the Image of the Body in an Ultra-Orthodox Jewish Context. Religion 46: 186-208. [CrossRef]

Epstein, Joseph, ed. 1981. Masters: Portraits of Great Teachers. New York: Basic Books.

Etkes, Immanuel. 1993. Rabbi Israel Salanter and the Mussar Movement: Seeking the Torah of Truth. Translated by Jonathan Chipman. Philadelphia: Jewish Publication Society.

Etkes, Immanuel. 2005. Rabbi Shneur Zalman of Liady: The Origins of Habad Hasidism. Translated by Jeffrey M. Green. Waltham: Brandeis University Press.

Etkes, Immanuel. 2007. A Shtetl with a Yeshiva: The Case of Volozhin. In The Shtetl: New Evaluations. Edited by Steven T. Katz. New York: New York University Press.

Feldman, Emanuel. 1996. The Editor's Notebook: The Halakhic Rebbe. Tradition: A Journal of Orthodox Jewish Thought 30: 1-4.

Fenton, Paul. 1991. The Hierarchy of the Saints in Jewish and Islamic Mysticism. Journal of the Muhyiddin Ibn'Arabi Society 10: 12-34.

Ferziger, Adam S. 2013. From Lubavitch to Lakewood: The Chabadization of American Orthodoxy. Modern Judaism 33: 101-24. [CrossRef]

Fine, Lawrence. 2003. Physician of the Soul, Healer of the Cosmos: Isaac Luria and His Kabbalistic Fellowship. Stanford: Stanford University Press.

Fine, Lawrence. 2013. Spiritual Friendship as Contemplative Practice in Kabbalah and Hasidism. In Meditations in Judaism, Christianity, and Islam: Cultural Histories. Edited by Halvor Eifring. London and New York: Bloomsbury Academic.

Fishbane, Eitan P. 2009. As Light Before Dawn: The Inner World of a Medieval Kabbalist. Stanford: Stanford University Press. Fishbane, Eitan P. 2012. Perceptions of Greatness: Constructions of the Holy Man in Shivhei ha-Ari. Kabbalah 27: 195-221. 
Fowler, James W. 1981. Stages of Faith: The Psychology of Human Development and the Quest for Meaning. San Francisco: Harper \& Row.

Fowler, James. 1996. Faithful Change: The Personal and Public Challenges of Postmodern Life. Nashville: Abingdon.

Fowler, James. 2001. Faith Development Theory and the Postmodern Challenges. The International Journal for the Psychology of Religion 11: 159-72. [CrossRef]

Fox, Seymour, Israel Scheffler, and Daniel Marom, eds. 2003. Visions of Jewish Education. Cambridge: Cambridge University Press.

Freire, Paulo. 2011. The 'Banking' Concept of Education. In Thinking about Schools: A Foundations of Education Reader. Edited by Eleanor Blair Hilty. Boulder: Westview Press.

Freire, Paulo. 2018. Pedagogy of Oppressed. Translated by Myra Bergman Ramos. New York: Bloomsbury Academic.

Friedman, Asher. 2003. As Gardeners in the Garden of God: Hasidic Thought and its Implications for Teacher-Student Relationships. In Wisdom From All My Teachers: Challenges and Initiatives in Contemporary Torah Education. Edited by Jeffrey Saks and Susan Handelman. Jerusalem and New York: Urim Publications.

Fynsk, Christopher. 2004. The Claim of Language: A Case for the Humanities. Minneapolis: University of Minnesota Press.

Gandolfo, Elizabeth. 2013. Mary Kept These Things, Pondering Them in Her Heart: Breastfeeding as Contemplative Practice and Source for Theology. Spiritus: A Journal of Christian Spirituality 13: 163-86. [CrossRef]

Garb, Jonathan. 2011. Shamanic Trance in Modern Kabbalah. Chicago: University of Chicago Press.

Geertz, Clifford. 2017. The Interpretation of Cultures. New York: Basic Books.

Gilat, Israel Zvi. 1995. Whose Obligation is it to Educate a Child in Religious Observance? Sidra: A Journal for the Study of Rabbinic Literature 11: 21-37. (In Hebrew)

Gilat, Israel Zvi. 2015. Halakhic Changes in the Interpretation of the Commandment to Educate a Child to Observe Commandments. Review of Rabbinic Judaism 18: 75-101. [CrossRef]

Giordan, Giuseppe, ed. 2010. Youth and Religion. Leiden and Boston: Brill.

Goldberg, Hillel. 1987. Rabbi Isaac Hutner: A Synoptic Interpretive Biography. Tradition: A Journal of Orthodox Jewish Thought 22: 18-46.

Goldberg, Hillel. 1989. Between Berlin and Slobodka: Jewish Transition Figures From Eastern Europe. Hoboken: Ktav Publishing House.

Good, Marie, and Teena Willoughby. 2008. Adolescence as a Sensitive Period for Spiritual Development. Child Development Perspectives 2: 32-37. [CrossRef]

Goshen-Gottstein, Alon. 2019. Rediscovering the Covenant: The Contemporary Hasidic Thought of Rabbi Shmuel Berezovsky of Slonim. In Be-Ron Yahad: Studies in Jewish Thought and Theology in Honor of Nehemia Polen. Edited by Ariel Evan Mayse and Arthur Green. Boston: Academic Studies Press.

Graham, William. 1987. Beyond the Written Word: Oral Aspects of Scripture in the History of Religion. Cambridge and New York: Cambridge University Press.

Green, Arthur. 1977. The Żaddiq as Axis Mundi in Later Judaism. Journal of the American Academy of Religion 45: 327-47. [CrossRef]

Green, Arthur. 2013a. Speaking Torah: Spiritual Teachings from Around the Maggid's Table. Translated by Ebn Leader, Ariel Evan Mayse, and Or Rose. Woodstock: Jewish Lights.

Green, Arthur. 2013b. Hasidism and its Response to Change. Jewish History 27: 334-35. [CrossRef]

Green, Arthur. 2013c. The Hasidic Homily: Mystical Performance and Hermeneutical Process. In As a Perennial Spring: A Festschrift Honoring Rabbi Dr. Norman Lamm. Edited by Benzi Cohen. New York: Downhill Publishing.

Green, Arthur. 2015. God's Need for Man: A Unitive Approach to the Writings of Abraham Joshua Heschel. Modern Judaism 35: 247-61. [CrossRef]

Green, Arthur, and Ariel Evan Mayse. 2016. 'The Great Call of the Hour': Hillel Zeitlin's Yiddish Writings on Yavneh. In Geveb: A Journal of Yiddish Studies. Available online: https://ingeveb.org/articles/the-great-call-ofthe-hour-hillel-zeitlins-yiddish-writings-on-yavneh (accessed on 1 May 2019).

Green, Arthur. Forthcoming. The Hasidic Tsaddik and the Charisma of Relationship.

Grene, Marjorie Glicksman. 1966. The Knower and the Known. New York: Basic Books.

Guenther, Margaret. 1992. Holy Listening: The Art of Spiritual Direction. Boston: Cowley Publications.

Halbertal, Moshe. 1997. People of the Book: Canon, Meaning and Authority. Cambridge: Harvard University Press.

Halivni, David Weiss. 1996. The Book and the Sword: A Life of Learning in the Shadow of Destruction. New York: Farrar, Straus and Giroux.

Hall, Thelma. 1988. Too Deep for Words: Rediscovering Lectio Divina. New York and Mahwah: Paulist Press. 
Handelman, Susan. 1992. 'Emunah': The Craft of Faith. CrossCurrents 42: 293-313.

Handelman, Susan. 2012. Make Yourself a Teacher: Rabbinic Tales of Mentors and Disciples. Seattle: University of Washington Press.

Harrison, Paul. 2003. Mediums and Messages: Reflections on the Production of Mahayana Sutra. Eastern Buddhist 35: $115-51$.

Hartman, David. 2003. Prayer and Religious Consciousness: An Analysis of Jewish Prayer in the Works of Joseph B. Soloveitchik, Yeshayahu Leibowitz, and Abraham Joshua Heschel. Modern Judaism 23: 105-25. [CrossRef]

Hartstein, Jacob I. 1947. The Yeshivah as an American Institution. Jewish Education 18: 26-39. [CrossRef]

Haskell, Ellen Davina. 2012. Suckling at My Mother's Breasts: The Image of a Nursing God in Jewish Mysticism. Albany: State University of New York Press.

Heilman, Samuel. 1992. Defenders of the Faith: Inside Ultra-Orthodox Jewry. Berkeley and Los Angeles: University of California Press.

Helmreich, William B. 1982. The World of the Yeshiva: An Intimate Portrait of Orthodox Jewry. New York: Free Press.

Hemer, Susan R. 2012. Informality, Power and Relationships in Postgraduate Supervision: Supervising PhD Candidates over Coffee. Higher Education Research \& Development 31: 827-39.

Herskowitz, Daniel, and Alon Shalev. 2018. Being-towards-Eternity: R. Isaac Hutner's Adaptation of a Heideggerian Notion. The Journal of Jewish Thought and Philosophy 26: 254-77. [CrossRef]

Heschel, Abraham Joshua. 1966. Jewish Education. In Insecurity of Freedom: Essays on Human Existence. New York: Schocken.

Heschel, Abraham Joshua. 1976. God in Search of Man: A Philosophy of Judaism. New York: Farrar, Straus and Giroux.

Heschel, Abraham Joshua. 1996. Hasidism as a New Approach to Torah. In Moral Grandeur and Spiritual Audacity. Edited by Susannah Heschel. New York: Farrar, Straus and Giroux.

Hundert, Gershon D. 2004. Jews in Poland-Lithuania in the Eighteenth Century: A Genealogy of Modernity. Berkeley and Los Angeles: University of California Press.

Hyde, Kenneth E. 1990. Religion in Childhood and Adolescence: A Comprehensive Review of the Research. Birmingham: Religious Education Press.

Idel, Moshe. 2012. 'The Besht Passed his Hand Over his Face': On the Besht's Influence on His Followers-Some Remarks. In After Spirituality: Studies in Mystical Traditions. Edited by Philip Wexler and Jonathan Garb. New York: Peter Lang.

Idel, Moshe. 2015. 'Higher than Time': Observations on Some Concepts of Time in Kabbalah and Hasidism. In Time and Eternity in Jewish Mysticism: That Which is Before and Which is After. Edited by Brian Ogren. Leiden and Boston: Brill.

Jacobs, Louis. 1996. Hasidism and the Dogma of the Decline of the Generations. In Hasidism Reappraised. Edited by Ada Rapoport-Albert. Lndon and Portland: Vallentine Mitchell.

Jacobs, Louis. 2005. Their Heads in Heaven: Unfamiliar Aspects of Hasidism. London and Portland Oregon: Vallentine Mitchell.

Jacobson, Jessica. 2006. Islam in Transition: Religion and Identity Among British Pakistani Youth. London: Routledge.

Jacobson-Maisels, James. 2016. Embodied Epistemology: Knowing through the Body in Late Hasidism. The Journal of Religion 96: 185-211. [CrossRef]

Jaffe, Martin S. 1997. A Rabbinic Ontology of the Written and Spoken Word: On Discipleship, Transformative Knowledge, and the Living Texts of Oral Torah. Journal of the American Academy of Religion 65: 525-49. [CrossRef]

Kanarek, Jane L., and Marjorie Lehman, eds. 2016. Learning to Read Talmud: What it Looks Like and How it Happens. Boston: Academic Studies Press.

Kaplan, Lawrence J. 1980. Rabbi Isaac Hutner's 'Daat Torah Perspective' on the Holocaust: A Critical Analysis. Tradition: A Journal of Orthodox Jewish Thought 18: 235-48.

Kaplan, Lawrence J. 2010. A Righteous Judgment on a Righteous People: Rav Yitzhak Hutner's Implicit Theology of the Holocaust. Hakirah: The Flatbush Journal of Jewish Thought 10: 101-15.

Kasher, Hannah. 1994. Self-Cognizing Intellect and Negative Attributes in Maimonides' Theology. Harvard Theological Review 87: 461-72. [CrossRef]

Kauffman, Tsippi. 2009. In all Your Ways Know Him: The Concept of God and Avodah be-Gashmiyut in the Early Stages of Hasidism. Ramat-Gan: Bar-Ilan University Press. (In Hebrew)

Kellner, Menachem. 1996. Maimonides on the "Decline of the Generations" and the Nature of Rabbinic Authority. Albany: State University of New York. 
Kongtrul, Jamgon. 1999. The Teacher-Student Relationship. Translated by Ron Garry. Ithaca: Snow Lion.

Lamm, Norman. 1989. Torah Lishmah: Torah for Torah's Sake in the Works of Rabbi Hayyim of Volozhin and His Contemporaries. Hoboken: KTAV Publishing House, Inc.

Lave, Jean. 1993. The Practice of Learning: The Problem with 'Context'. In Understanding Practice: Perspectives on Activity and Context. Edited by Seth Chaiklin and Jean Lave. Cambridge and New York: Cambridge University Press.

Lave, Jean, and Etienne Wenger. 1991. Situated Learning: Legitimate Peripheral Participation. Cambridge and New York: Cambridge University Press.

Leader, Ebn. 2019. Leadership as Individual Relationships: A Close Study of the No'am Elimelekh. In Be-Ron Yahad: Studies in Jewish Thought and Theology in Honor of Nehemia Polen. Edited by Ariel Evan Mayse and Arthur Green. Boston: Academic Studies Press.

Lebra, Takie Sugiyama. 1987. The Cultural Significance of Silence in Japanese Communication. Multilingua-Journal of Cross-Cultural and Interlanguage Communication 6: 343-58. [CrossRef]

Lee, Philip. 2011. The Curious Life of In Loco Parentis at American Universities. Higher Education in Review 8: 65-90.

Lehman, Marjorie, and Jane Kanarek. 2011. Talmud: Making a Case for Talmud Pedagogy—The Talmud as an Educational Model. In International Handbook of Jewish Education. Edited by Helena Miller, Lisa D. Grant and Alex Pomson. Dordrecht: Springer.

Leshem, Zvi. 2018. Emotional Hasidic Education as a Response to Secularization in the Writings of R. Kalonymus Kalmish Shapira of Piaseczna. Mikhlol-Pardes 2: 37-61. (In Hebrew)

Levisohn, Jon A., and Susan P. Fendrick, eds. 2013. Turn It and Turn It Again: Studies in the Teaching and Learning of Classical Jewish Texts. Boston: Academic Studies Press.

Liebes, Yehuda. 1982. The Messiah of the Zohar: On R. Simeon bar Yohai as a Messianic Figure. In Studies in the Zohar. Translated by Arnold Schwartz, Stephanie Nakache, and Penina Peli. Albany: State University of New York Press.

Lobel, Diana. 2002. 'Silence Is Praise to You': Maimonides on Negative Theology, Looseness of Expression, and Religious Experience. American Catholic Philosophical Quarterly 76: 25-49. [CrossRef]

Lull, David J. 1986. 'The Law as Our Pedagogue': A Study in Galatians 3:19-25. Journal of Biblical Literature 105: 481-98. [CrossRef]

Maayan, David. 2017. The Call of the Self: Devotional Individuation in the Teachings of Rabbi Kalonymous Kalman Shapira of Piaseczno. Master's thesis, Hebrew College, Newton Centre, MA, USA.

Magid, Shaul. 2000. Deconstructing the Mystical: The Anti-Mystical Kabbalism in Rabbi Hayyim of Volozhin's Nefesh Ha-Hayyim. The Journal of Jewish Thought and Philosophy 9: 21-67. [CrossRef]

Magid, Shaul. 2012. From Sainthood to Selfhood in American Judaism: Artscroll's New Jewish Hero and Jewish Renewal's Functional Rebbe. Modern Judaism 32: 270-92. [CrossRef]

Malamud, Margaret. 1996. Gender and Spiritual Self-Fashioning: The Master-disciple Relationship in Classical Sufism. Journal of the American Academy of Religion 64: 89-117. [CrossRef]

Margolin, Ron. 2005. Human Temple: Religious Interiorization and the Structuring of Inner Life in Early Hasidism. Jerusalem: Magnes Press. (In Hebrew)

Mayse, Ariel Evan. 2018. Like a Blacksmith with the Hammer: Talmud Study and the Spiritual Life. In The Search for Meaning. Edited by Martin S. Cohen and David Birnbaum. New York: Mesorah Matrix.

Mayse, Ariel Evan. 2019a. Yokhed ve-tsiber: Individual Expression and Communal Responsibility in a Yiddish Droshe by Rabbi Joseph B. Soloveitchik. Geveb, February 11.

Mayse, Ariel Evan. 2019b. The Voices of Moses: Theologies of Revelation in an Early Hasidic Circle. Harvard Theological Review 112: 101-25. [CrossRef]

Mayse, Ariel Evan, and Daniel Reiser. 2018. Territories and Textures: The Hasidic Sermon as the Crossroads of Language and Culture. Jewish Social Studies 24: 127-60. [CrossRef]

Mayse, Ariel Evan. Forthcoming a. Speaking Infinities: God and Language in the Teachings of Rabbi Dov Ber Friedman. Philadelphia: University of Pennsylvania Press.

Mayse, Ariel Evan. Forthcoming b. 'Moving Mezritsh': The Legacy of the Maggid and the Hasidic Community in the Land of Israel. Jewish History.

Mayse, Ariel Evan. Forthcoming c. The Devotional Talmud: Study as a Sacred Quest. In Rabbi Kalonymus Shapira: On Literature, Vitality and Death. Edited by Don Seeman, Daniel Reiser and Ariel Evan Mayse. 
Mayse, Ariel Evan. Forthcoming d. Wading into Infinite Waters: Mediation in Theology, Pedagogy and Revelation. In Ways of Learning, Ways of Becoming: Neo-Hasidic Teaching of the Hasidic Homily. Edited by Elie Holzer. Boston: Academic Studies Press.

Mendelssohn, Moses. 1986. Jerusalem: Or on Religious Power and Judaism. Translated by Allan Arkush. Hanover and London: Brandeis University Press.

Mezirow, Jack. 1991. Transformative Dimensions of Adult learning. San Francisco: Jossey-Bass.

Mezirow, Jack. 1996. Contemporary Paradigms of Learning. Adult Education Quarterly 46: 158-72. [CrossRef]

Mirsky, Yehuda. 2014. Rav Kook: Mystic in a Time of Revolution. New Haven: Yale University Press.

Nardi, Bonnie A. 1996. Studying Context: A Comparison of Activity Theory, Situated Action Models, and Distributed Cognition. In Context and Consciousness: Activity Theory and Human-Computer Interaction. Cambridge: MIT Press.

Nasr, Seyyed Hossein. 1989. Knowledge and the Sacred. Albany: State University of New York.

O'Sullivan, Edmund. 2003. Bringing a Perspective of Transformative Learning to Globalized Consumption. International Journal of Consumer Studies 27: 326-30. [CrossRef]

Palmer, Parker. 1993. To Know as We Are Known: Education as a Spiritual Journey. New York: HarperCollins.

Polanyi, Michael. 1962. Personal Knowledge: Towards a Post-Critical Philosophy. Chicago: The University of Chicago Press.

Polen, Nehemia. 2010. Derashah as Performative Exegesis. In Midrash and the Exegetical Mind. Edited by Lieve Tuegels and Rivka Ulmer. Piscataway: Gorgias Press.

Polen, Nehemia. 2015. Hasidic Derashah as Illuminated Exegesis. In The Value of the Particular: Lessons from Judaism and the Modern Jewish Experience. Festschrift for Steven T. Katz on the Occasion of His Seventieth Birthday. Edited by Michael Zank and Ingrid Anderson. Leiden and Boston: Brill.

Rapoport-Albert, Ada. 1979. God and the Zaddik as the two Focal Points of Hasidic Worship. History of Religions 18: 296-325. [CrossRef]

Rinpoche, Patrul. 1998. How to Follow a Spiritual Friend. In Kunzang Lama'i Shelung = The Words of My Perfect Teacher. Boston: Shambhala.

Robbins, Thomas, Dick Anthony, and Thomas Curtis. 1975. Youth Culture Religious Movements: Evaluating the Integrative Hypothesis. The Sociological Quarterly 16: 48-64. [CrossRef]

Robertson, Duncan. 2011. Lectio Divina: The Medieval Experience of Reading. Collegeville: Liturgical Press.

Rubenstein, Jeffrey L. 1999. Talmudic Stories: Narrative Art, Composition, and Culture. Baltimore: Johns Hopkins University Press.

Sagi, Avi. 2008. Halakhah in the Thought of Leibowitz and Soloveitchik. In Tradition vs. Traditionalism: Contemporary Perspectives in Jewish Thought. Amsterdam and New York: Rodopi.

Schachter-Shalomi, Zalman Meshullam. 1991. Spiritual Intimacy: A Study of Counseling in Hasidism. Northvale: Jason Aronson Inc.

Schacter, Jacob J. 1990. Haskalah, Secular Studies and the Close of the Yeshiva in Volozhin in 1892. The Torah U-Madda Journal 2: 76-133.

Scholem, Gershom. 1995. Revelation and Tradition as Religious Categories in Judaism. In The Messianic Idea in Judaism and Other Essays on Jewish Spirituality. New York: Schocken Books.

Scholem, Gershom. 1997. Tzaddik: The Righteous One. In On the Mystical Shape of the Godhead: Basic Concepts in the Kabbalah. New York: Schocken Books.

Schwarzschild, Steven S. 1985. An Introduction to the Thought of R. Isaac Hutner. Modern Judaism 5: $235-77$. [CrossRef]

Seligman, Adam B., Robert P. Weller, Michael J. Puett, and Bennett Simon. 2008. Ritual and its Consequences: An Essay on the Limits of Sincerity. Oxford: Oxford University Press.

Shalev, Alon. 2013. Major Themes in the Biography and Thought of Rabbi Isaac Hutner. Master's thesis, Ben Gurion University of the Negev, Beersheba, Israel. (In Hebrew).

Sharot, Stephen. 1980. Hasidism and the Routinization of Charisma. Journal for the Scientific Study of Religion 19: 325-36. [CrossRef]

Shire, Michael J. 2011. Spirituality: The Spiritual Child and Jewish Childhood. In International Handbook of Jewish Education. Edited by Helena Miller, Lisa D. Grant and Alex Pomson. Dordrecht: Springer.

Shonkoff, Sam Berrin. 2012. We Shall Do and We Shall Understand: Halakhah, Habitus, and Embodied Theology in Judaism. Journal of Religion and Culture 23: 15-37.

Shulman, Lee S. 1986. Those who Understand: Knowledge Growth in Teaching. Educational Researcher 15: 4-14. [CrossRef] 
Silverstein, Yaron. 2010. Educational Aspects of the Outlook of Rabbi Yitzhak-Zeev Soloveitchik. Hagut: Studies in Jewish Educational Thought 9: 111-36. (In Hebrew).

Solomon, Aryeh. 2000. The Educational Teachings of Rabbi Menachem M. Schneerson. Northvale: Jason Aronson Inc. Soloveitchik, Joseph B. 2009. Yokhed ve-tsiber. In Yiddish Drashos and Writings (Drashos un Ksovim). Edited by David E. Fishman. Jersey City: Ktav Publishing House.

Stampfer, Shaul. 1996. Hasidic Yeshivot in Inter-War Poland. Polin 11: 3-24.

Stampfer, Shaul. 2012. Lithuanian Yeshivas of the Nineteenth Century: Creating a Tradition of Learning. Translated by Lindsey Taylor-Guthartz. Oxford and Portland: Littman Library of Jewish Civilization.

Steiner, George. 2003. Lesson of the Masters. Cambridge and London: Harvard University Press.

Tikochinski, Shlomo. 2009. Musar Yeshivot from Lithuania to Israel: Slabodka Yeshiva, its Emigration and Establishment in Mandate Palestine. Ph.D. Dissertation, Hebrew University, Jerusalem, Israel. (In Hebrew)

Tirri, Kirsi, Jukka Husu, and Pertti Kansanen. 1999. The Epistemological Stance between the Knower and the Known. Teaching and Teacher Education 15: 911-22. [CrossRef]

Tsongkhapa, and Je Tsongkhapa. 1999. The Fulfillment of All Hopes: Guru Devotion in Tibetan Buddhism. Translated by Gareth Sparham. Boston: Wisdom Publications.

Turner, Victor. 1977. The Ritual Process: Structure and Anti-Structure. Ithaca: Cornell University Press.

Turner, Yossi. 2000. Rabbi Chaim Hirschensohn's Israel Education Theory. Hagut: Studies in Jewish Educational Thought 2: 201-21. (In Hebrew)

Twersky, Isadore. 1967. Some Non-Halakic Aspects of the Mishneh Torah. In Jewish Medieval and Renaissance Studies. Edited by Alexander Altmann. Cambridge: Harvard University Press.

Twersky, Isadore. 1980. Introduction to the Code of Maimondies (Mishneh Torah). New Haven: Yale University Press. Venable, Stephen F. 1997. Adolescent Rites of Passage: An Experiential Model. Journal of Experiential Education 20: 6-13. [CrossRef]

Walfish, Miriam-Simma. 2017. Upending the Curse of Eve: A Reframing of Maternal Breastfeeding in BT Ketubot. In Motherhood in the Jewish Cultural Imagination. Edited by Marjorie Lehman, Jane L. Kanarek and Simon J. Broner. Liverpool: Littman.

Weiss, Joseph G. 1997. R. Abraham Kalisker's Concept of Communion with God and Men. In Studies in Eastern Jewish Mysticism and Hasidism. Edited by David Goldstein. Oxford: Littman Library of Jewish Civilization.

Weiss, Asher. 2017. Minhat Asher 'al ha-Torah. Jerusalem, n.p. Bereshit 21: 127-34.

Wenger, Etienne. 1998. Communities of Practice: Learning, Meaning, and Identity. Cambridge: Cambridge University Press. Wexler, Philip. 2014. Toward a Cosmic Sociology of Education. Critical Studies in Education 55: 73-86. [CrossRef] Wolfson, Harry A. 1965. Maimonides on the Unity and Incorporeality of God. The Jewish Quarterly Review 56: 112-36. [CrossRef]

Worley, Virginia. 2003. Response: The Teacher's Place in the Moral Equation: In Loco Parentis. Philosophy of Education Yearbook, 280-82.

Wringe, Colin. 2009. Teaching Learning and Discipleship: Education Beyond Knowledge Transfer. Journal of Philosophy of Education 43: 239-51. [CrossRef]

Yannicopoulos, A. V. 1985. The Pedagogue in Antiquity. British Journal of Educational Studies 33: 173-79. [CrossRef]

Young, Norman H. 1987. Paidagogos: The Social Setting of a Pauline Metaphor. Novum Testamentum 29: 150-76. [CrossRef]

Zelden, Michael. 1995. Touching the Future: The Promise of Mentoring. In Touching the Future: Mentoring and the Jewish Professional. Edited by Michael Zeldin and Sara S. Lee. Los Angeles: HUC-JIR.

Zembylas, Michalinos, and Pavlos Michaelides. 2004. The Sound of Silence in Pedagogy. Educational Theory 54: 193-210. [CrossRef]

(C) 2019 by the author. Licensee MDPI, Basel, Switzerland. This article is an open access article distributed under the terms and conditions of the Creative Commons Attribution (CC BY) license (http://creativecommons.org/licenses/by/4.0/). 